\author{
Małgorzata Omilanowska \\ (Instytut Historii Sztuki, Uniwersytet Gdański) \\ https://orcid.org/0000-0001-9766-0424
}

\title{
Gdyńska architectura militaris autorstwa Mariana Lalewicza
}

\author{
DOI: https://doi.org/10.26881/porta.2019.18.06
}

Zespół Dowództwa Floty i koszar Marynarki Wojennej na Oksywiu w Gdyni stanowi jeden z najciekawszych przykładów architektury wojskowej czasów II Rzeczypospolitej. Wielki kompleks urbanistyczno-architektoniczny był dziełem jednego architekta, powstał w krótkim czasie i w zasadniczym zrębie w jednolitych formach architektonicznych, choć doczekał się także późniejszych uzupełnień już w innej konwencji stylowej. Był jedną z pierwszych inwestycji polskich sił zbrojnych na tę skalę po odzyskaniu niepodległości i zarówno pod względem funkcjonalnym, jak i formalnym miał w założeniu stać się wzorcowym przykładem tworzenia nowej architektury na potrzeby wojska polskiego w odrodzonym państwie ${ }^{1}$.

Marynarka Polska utworzona została dekretem marszałka Józefa Piłsudskiego już 28 listopada 1918 r., początkowo jako Sekcja Marynarki pod dowództwem Bogumiła Nowotnego przy Ministerstwie Spraw Wojskowych, a dekretem z 14 maja 1919 r. jako Departament dla Spraw Morskich, którego szefem został kontradmirał Kazimierz Porębski². Pierwsza Komendantura Portu Wojennego powstała w Modlinie. Polska objęła we władanie odcinek wybrzeża dopiero w 1920 r., a symboliczne zaślubiny Polski z morzem miały miejsce 10 lutego $1920 \mathrm{r}$. Tego samego dnia sejm uchwalił ustawę o budowie polskiego portu morskiego w Gdyni. Pierwszą bazą morską dla Marynarki Wojennej stał się port w Pucku, w którym ulokowano siedzibę Dowództwa Wybrzeża Morskiego, przemianowanego w 1922 r. na Dowództwo Floty, a pierwszym dowódcą został komandor Jerzy Świrski. Tam też w 1920 r. rozlokowano nie tylko oddziały świeżo powołanej floty morskiej, lecz także rozmaite jednostki zajęte jej organizacją, które wykorzystywały częściowo pruskie budynki powojskowe, częściowo zaś

1 Jan Modest Łobecki, Architectura militaris Polona 1918-1978 [w:] Architektura i urbanistyka w Polsce w latach 1918-1978, Warszawa 1989 (Studia i Materiały do Teorii i Historii Architektury i Urbanistyki, t. 18), s. 93-120.

2 Józef Boreyko, Marynarka wojenna [w:] Dziesięciolecie odrodzenia Polskiej Sity Zbrojnej 1918-1928, red. Henryk Mościcki, Włodzimierz Dzwonkowski, Tadeusz Bałaban, Warszawa 1928, s. 456-472, tu s. 458-459; Czesław Ciesielski, Powstanie Marynarki Wojennej i jej udział w rozwoju Gdyni [w:] Dzieje Gdyni, red. Roman Wapiński, Wrocław-Warszawa-Kraków-Gdańsk, 1980, s. 62-74. 
korzystały z wynajętych domów³. Decyzją z 14 listopada 1921 r. Departament Spraw Morskich został pozbawiony kontroli nad marynarką handlową, a od stycznia 1922 r. - przekształcony w Kierownictwo Marynarki Wojennej, którym nadal dowodził wiceadmirał Porębski. To dzięki jego staraniom podjęto budowę portu wojennego w Gdyni, który wyznaczono u ujścia potoku pomiędzy Kępą Oksywską a Kamienną Górą.

Początkowo sprawy budowlane na Wybrzeżu znajdowały się w zakresie kompetencji Zarządu Budowlano-Kwaterunkowego, będącego organem wykonawczym Departamentu V Inżynierii i Saperów Ministerstwa Spraw Wojskowych ${ }^{4}$. W 1922 r. ustanowiono osobny Rejon Inżynieryjny Wybrzeża Morskiego, podległy dowódcy Floty, wówczas komandorowi Świrskiemu, ale zależny od wspomnianego departamentu w MSW. Budowa koszar i budynku Dowództwa Floty była w zakresie kompetencji kierownika wspomnianego Rejonu Inżynierii Wybrzeża Morskiego, przemianowanego w 1930 r. na Szefostwo Budownictwa Wybrzeża Morskiego, na czele którego od 1931 r. stał Zygmunt Horyd ${ }^{5}$.

Wytyczenie portu w Gdyni i wyznaczenie północnego nabrzeża projektowanego basenu portowego na potrzeby Marynarki Wojennej zdeterminowało lokalizację przyszłego zespołu koszarowego z siedzibą dowództwa. Pod budowę wybrano obszar, który „mógł być przez władze wojskowe bez dłuższych formalności zajęty"', a znajdował się u stóp i na stoku wzgórza - góry oksywskiej z kościołem parafialnym - ograniczony niewielką osadą kaszubską. ,Samo wzgórze - jak je opisywano w międzywojniu - całkiem puste, pokryte słabą roślinnością, zaledwie pokrywającą lotny piasek, zmywany przez deszcz lub strącany przez panujące tu wiatry, było przez wiele stuleci martwym miejscem, zwiedzanym li tylko przez owce ze wsi zbłąkane. [...] Nie widział nikt też z okolicznych mieszkańców, a tym bardziej i ci, co z łopatą i oskardem do robót ziemnych tu przystąpili, że miejsce to miejscem zmarłych było" ". Znalezione wówczas cmentarzysko prehistoryczne eksplorowano naprędce, wydobywając urny grobowe, broń i biżuterię, tak aby jak najszybciej przystąpić do rozplanowania całego zespołu. „Szczególny układ terenowy z silnymi spadkami ku południu biegnącymi zmusił do wykorzystania możliwie całkowitego niższych terenów, więcej płaskich".

Budowę portu rozpoczęto w 1921 r., a już 29 kwietnia 1923 r. nastąpiło otwarcie tzw. Tymczasowego Portu Wojennego i Schroniska dla Rybaków. Budowa portu właściwego postępowała szybko i wizja rychłego ukończenia spowodowała, że w $1923 \mathrm{r}$. podjęto projektowanie założenia koszarowego. Jak pisał anonimowy reporter „Morza”: „Ponieważ oczy nie tylko społeczeństwa polskiego, lecz

3 Budownictwo wojskowe 1918-1935. Historia, przepisy, zasady, normy, red. Aleksander Król, t. 2, Warszawa 1935, s. 518.

4 Ibidem, s. 490.

Ibidem, s. 492.

Ibidem, s. 518.

7 Ibidem.

8 Ibidem, s. 519. 
Małgorzata Omilanowska i naszych sąsiadów z uwagą śledziły każde zamierzenie Polski co do utrwalenia swego panowania nad morzem, przeto zadania budownictwa Marynarki były o wiele ważniejsze, niż na pierwszy rzut oka można by sądzić; toteż Marynarka troskliwie dobierała projektodawców i wyrazicieli jej idei. Jednym z tych, który najlepiej rozwiązał przyjęte na siebie zadanie, jest prof. architekt M. Lalewicz"

Przy dzisiejszym stanie badań nie sposób ustalić, dlaczego właśnie Marian Lalewicz został wybrany do tego zadania, architekt ten nie był bowiem ani wcześniej, ani później angażowany do projektów realizowanych przez siły zbrojne. Na zespół oksywski nie ogłoszono żadnego konkursu, decyzja musiała więc zapaść w gabinecie albo kontradmirała Porębskiego, albo dowódcy Floty, komandora Świrskiego.

Lalewicz urodził się w 1876 r. w Wyłkowyszkach, szkołę średnią skończył w Suwałkach w 1895 r., a studia architektoniczne w petersburskiej Cesarskiej Akademii Sztuk Pięknych w 1901 r. ${ }^{10}$ Po studiach i wspartej stypendium długiej, studialnej podróży po Europie osiadł w 1902 r. w Petersburgu. W ciągu kolejnych kilkunastu lat zdołał osiągnąć, chyba najwyższą wśród Polaków, pozycję $\mathrm{w}$ architektonicznym środowisku stolicy cesarstwa. Projektował, budował, ale też uczył w szkołach architektonicznych i sporo udzielał się społecznie, zarówno w środowisku zawodowym, jak i na innych polach. Rosję opuścił najpewniej późną wiosną bądź wczesnym latem 1918 r. i wraz z rodziną - miał już wtedy żonę i dwóch synów - osiadł w Warszawie. Natychmiast włączył się w życie

9 Marynarka Wojenna. Budownictwo Marynarki Wojennej, „Morze. Organ Ligi Morskiej i Rzecznej” 1927, nr 11, s. 11.

10 Hasła leksykograficzne, zob. m.in. Lech Niemojewski, Wspomnienie pośmiertne: Marian Lalewicz (1876-1944), „Rocznik Towarzystwa Naukowego Warszawskiego” 1938-1945, nr 31-38, s. 212-214; Jan Zachwatowicz, Lalewicz Marian [w:] Polski słownik biograficzny, t. 16, WrocławWarszawa-Kraków 1971, s. 413-414; Светлана, С. Левошко, Лялевич Марианн Станиславович, http://www.artrz.ru/search/Лялевич [dostęp: 20.08.2019]; Piotr Kibort, Marian Lalewicz, Culture-pl, https://culture.pl/pl/tworca/marian-lalewicz [dostęp: 10.09.2019]; Andrzej Skalimowski, Marian Lalewicz [w:] Polski Petersburg, Kraków 2017, http://www.polskipetersburg.pl/hasla/lalewicz-marian [dostęp: 10.08.2019]; Katarzyna Dankiewicz, Marian Lalewicz [w:] 100 lat Wydziału Architektury Politechniki Warszawskiej 1915-2015. Nauczyciele, red. Jadwiga Roguska, Stefan Wrona i in., Warszawa 2018, s. 341-343. Artykuły, zob. Małgorzata Omilanowska, Działalność Mariana Lalewicza $w$ Petersburgu, „Przegląd Wschodni” 1991, nr 1, s. 113-132; Jan Pruszyński, Profesor Marian Lalewicz (1876-1944), „Kwartalnik Architektury i Urbanistyki” 1993, z. 1, s. 57-70; Robert Pasieczny, Klasycyzm akademicki w twórczości Mariana Lalewicza [w:] Klasycyzm i klasycyzmy, Warszawa 1994, s. 205-209; Robert Pasieczny, Gusta kupca Mertensa [w:] De Gustibus: studia ofiarowane przez przyjaciół Tadeuszowi Stefanowi Jaroszewskiemu z okazji 65. rocznicy urodzin, red. Robert Pasieczny, Antoni Ziemba, Warszawa 1996, s. 202-211; Agata Wagner, Niezrealizowane plany Mariana Lalewicza rozbudowy Politechniki Warszawskiej na Polu Mokotowskim, „Kwartalnik Architektury i Urbanistyki” 1998, z. 4, s. 343-352; Edward Usakiewicz, Wspomnienia o profesorze Marianie Lalewiczu, „Kwartalnik Architektury i Urbanistyki” 2005, z. 3-4, s. 201-205; Agata Wagner, Gmach Państwowego Instytutu Geologicznego w Warszawie - przestrzenno-architektoniczne odniesienia Mariana Lalewicza do klasycyzmów w architekturze polskiej, „Kwartalnik Architektury i Urbanistyki” 2010, z. 4, s. 88-102; Jadwiga Roguska, Petersburskie wątki w warszawskiej twórczości architektonicznej Mariana Lalewicza [w:] Sztuka Europy Wschodniej, t. 6, Polscy i rosyjscy architekci XIX i XX wieku, red. Jerzy Malinowski, Irina Gavrash, Warszawa-Toruń 2018, s. 133-154. 
społeczne i architektoniczne miasta, podejmując pierwsze zadania już jesienią 1918 r. Następne dwadzieścia lat spędził na działalności architektonicznej, uprawiał także dydaktykę, publicystykę architektoniczną, tłumaczył zawodowe teksty i udzielał się społecznie. Zginął podczas powstania warszawskiego, rozstrzelany wraz z grupą ludności cywilnej w dniu 17 września 1944 r.

Niemal natychmiast po przeprowadzce do Polski, już w styczniu 1919 r. Lalewicz został powołany na stanowisko Naczelnika Budownictwa Państwowego w Ministerstwie Robót Publicznych, co wiązało się z powierzeniem mu prac adaptacyjnych przy warszawskich pałacach przeznaczonych na siedziby rządu i agent rządowych. Przeprowadzono je wszystkie w zasadniczym zrębie w latach 1919- $1921^{11}$. Były to przede wszystkim prace w takich gmachach, jak pałac Namiestnikowski przy Krakowskim Przedmieściu 46, adaptowany na potrzeby siedziby Rady Ministrów, rządowe gmachy corazziańskie przy ulicy Rymarskiej 1-3-5, przebudowane na potrzeby Ministerstwa Skarbu, pałac Raczyńskich przy ulicy Długiej 7, przygotowany na potrzeby Ministerstwa Sprawiedliwości, pałac Badenich przy pl. Krasińskich, przeznaczony dla Sądu Apelacyjnego. Lalewicz prowadził też prace przy pałacu Brühla (zbudował tam zespół garaży od ulicy Wierzbowej) dla Ministerstwa Spraw Zagranicznych, wykonał także wstępną adaptację pałacu Prymasowskiego przy ulicy Senatorskiej na siedzibę Muzeum Rolnictwa.

W tym miejscu przypomnę, że zanim kontradmirał Porębski został dowódcą polskiej Marynarki Wojennej, po ukończeniu studiów wojskowych w Petersburgu i Kronsztadzie, od 1896 do 1918 r. służył w Marynarce Wojennej Rosji. Być może więc architekt i kontradmirał poznali się jeszcze w Petersburgu. Istnieje też możliwość, że zawiązali kontakty w Warszawie, np. w związku ze wspomnianym zaangażowaniem Lalewicza w prace dla rządu. Nie można też wykluczyć, że wybór Lalewicza był decyzją komandora Świrskiego, oficera Marynarki Wojennej Rosji, który w latach 1889-1902 uczył się w Morskim Korpusie w Petersburgu, a więc w tym samym okresie, kiedy w mieście studiował także Lalewicz. Niestety, nie ocalało prywatne archiwum Lalewicza, natomiast należąca do władz wojskowych dokumentacja budowy zespołu oksywskiego zachowała się jedynie szczątkowo, co nie pozwoli mi na udzielenie jednoznacznej odpowiedzi na postawione wyżej pytanie ${ }^{12}$. Za to istnieje do dzisiaj sam zespół gmachów, który pomimo adaptacji najpierw na potrzeby utworzonego w 1935 r. Centrum Wyszkolenia Specjalistów Floty, a po wojnie - rozbudowy Oficerskiej Szkoły Marynarki Wojennej, od 1955 r. przemianowanej na Wyższą Szkoły Marynarki Wojennej i przekształconej w 1987 r. w Akademię Marynarki

11 Restauracja gmachów rządowych. Wywiad z prof. Marianem Lalewiczem. Rozmowę przeprowadził St. Zdz. [Stanisław Zdziarski?], „Rzeczpospolita” 1921, nr 83, wyd. por., s. 5-6.

12 Jeden z egzemplarzy (nr 3) projektu: Marynarka Wojenna. Dom Dowództwa Floty. Oksywie, sygnowany przez Mariana Lalewicza, jest zachowany w zbiorach jednostki wojskowej: Rejonowy Zarząd Infrastruktury - Gdynia. 
Małgorzata Omilanowska
Wojennej, nadal stanowi jeden z najlepszych przykładów monumentalnej architektury wojskowej czasów II Rzeczypospolitej ${ }^{13}$.

Pierwszym zadaniem Lalewicza było rozplanowanie urbanistyczne całego kompleksu, który miał się składać z siedziby Dowództwa Floty, budynków koszarowych wraz z zapleczem organizacyjnym i technicznym oraz domów mieszkalnych dla podoficerów i oficerów i ich rodzin. Architekt nie miał łatwego zadania, jak wynika bowiem z przytoczonego już opisu miejsca wybranego pod zabudowę, musiał poradzić sobie z rozlokowaniem zaplanowanych budynków na pochyłym terenie i niewielkim pasie wypłaszczenia dochodzącego do portu.

Lalewicz rozplanował całe założenie, wykorzystując schemat układu wachlarzowego (il. 1). Osią tego układu miał być niewielki kolisty plac (obecnie nieco zsunięte z dawnej osi Rondo Bitwy pod Oliwą), a podstawą wachlarza ograniczającą teren od południa, czyli od strony basenu portowego - ulica Okrężna (obecna ulica inż. Jana Śmidowicza), biegnąca od ronda ku zachodowi, oraz ulica Arciszewskich, łagodnie wspinająca się na wzgórze ku północnemu wschodowi. Rondo zostało domknięte od północy rozłożystym budynkiem bramnym na rzucie ćwierćkoła, którego trzy przeloty wyznaczały trzy główne osie założenia. Środkowa wiodła do gmachu Dowództwa Floty, prawa (wschodnia), pnąca się w górę po stoku wzgórza, stanowiła osnowę założenia mieszkalnego dla podoficerów i oficerów, zaś lewa (zachodnia) prowadziła wzdłuż zabudowań pomocniczych do domu podoficerskiego, a jej rozgałęzienie - ku wschodowi do zespołu koszarowego ( $w$ formie czworoboku) gmachów ustawionych wokół trapezowego placu musztry, zlokalizowanego na wypłaszczeniu u stóp wzgórza.

W układzie urbanistycznym tego założenia Maria Sołtysik dostrzegła wpływ urbanistyki francuskiej ${ }^{14}$. Angelika Pakizer wywiodła zaś związki układu oksywskiego z planami Wersalu, Karlsruhe i Petersburga, i ten ostatni trop wydaje się wskazywać na jedną z możliwych, bezpośrednich analogii ${ }^{15}$. Lalewicz mieszkał w Petersburgu ponad dwadzieścia lat, znał doskonale jego strukturę urbanistyczną i musiał zdawać sobie sprawę z jej zalet. Co istotne, trójosiowy wachlarz wielkich ulic - Wozniesienskiej, Gorochowej i Prospektu Newskiego - stanowiących szkielet urbanistyczny Petersburga, zbiega się w punkcie, gdzie wznosi się złocona iglica wieńcząca oś gmachu Admiralicji, czyli dowództwa floty imperium rosyjskiego, paralela ta wydaje się więc osadzona nie tylko $\mathrm{w}$ formie, ale i funkcji założenia.

13 Jerzy Chłopecki, Bogdan Piaseczny, Gmachy Akademii Marynarki Wojennej [w:] Ochrona zabytków architektury obronnej. Materiały Ogólnopolskiego Zjazdu Społecznych Opiekunów Zabytków i Wojewódzkich Konserwatorów Zabytków, Gdynia - Hel, 2-4 października 1998 r. W 80. rocznice, powstania Marynarki Wojennej RP, red. Bronisław Grzegorczyk, Gdynia-Hel 1998, s. 54-62.

14 Maria J. Sołtysik, Gdynia, miasto dwudziestolecia międzywojennego. Urbanistyka i architektura, Warszawa 1993, s. 68.

15 Angelika Pakizer, Architektura budynków koszarowych Marynarki Wojennej projektu Mariana Lalewicza na Oksywiu, praca mgr napisana na Wydziale Historycznym Uniwersytetu Gdańskiego, mpis, Gdańsk 2004, s. 38-42. 


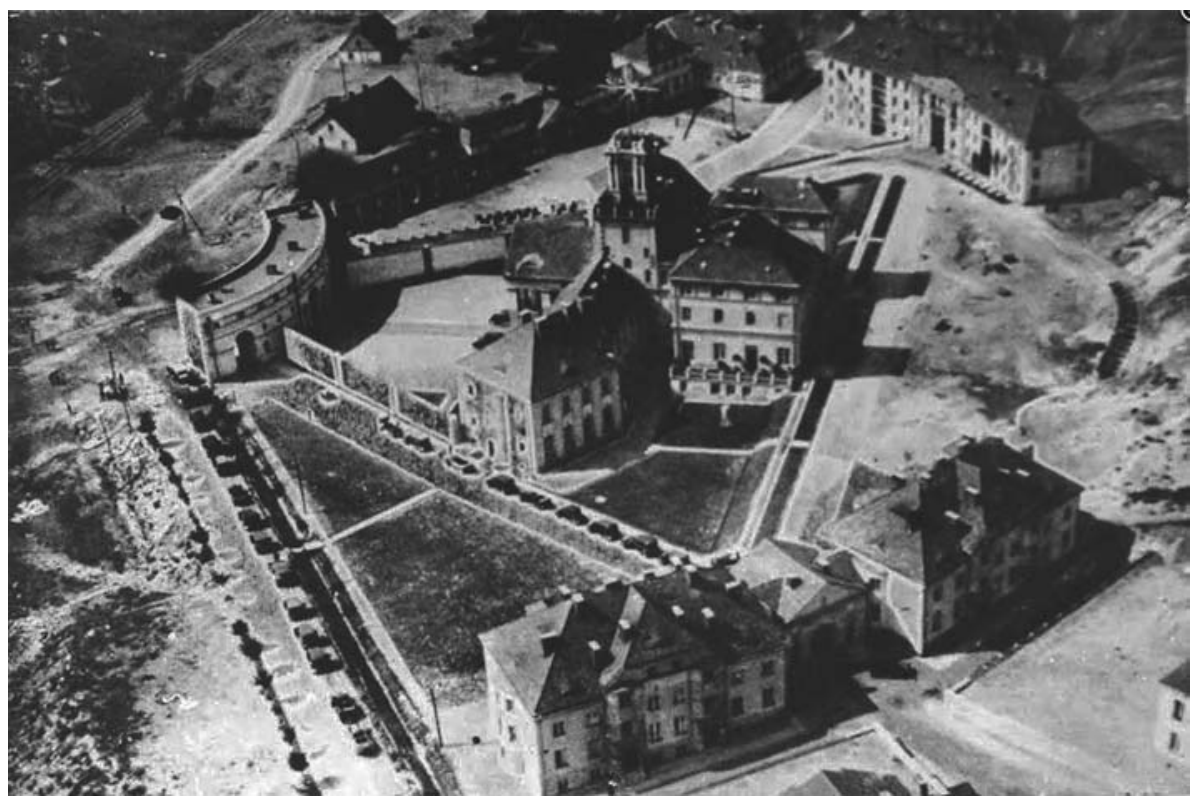

Gdyńska architectura militaris..

Il. 1. Gdynia, zespół Dowództwa Floty i koszar Marynarki Wojennej na Oksywiu, proj. Marian Lalewicz, fot. lotnicza z lat trzydziestych XX w., zbiory Muzeum Miasta Gdyni

Drugi możliwy trop wynika z podobieństw zespołu na Oksywiu - także architektonicznych, o czym będzie jeszcze mowa - do dzieł Claude'a-Nicolasa Ledoux i zaprojektowanego przezeń założenia królewskich salin w Arc-et-Senans. Ten ostatni kompleks, realizujący koncept miasta idealnego, wzniesiony „na surowym korzeniu” na rozległej równinie, zawiera się w precyzyjnie wykreślonym półkolu z wyraźnie zaznaczoną podstawą stanowiącą front i promieniście wytyczonymi alejkami komunikacyjnymi. Oczywiście, urbanistyka poszukująca idealnych rozwiązań zna takich pomysłów sporo, ale wskazanie salin czyni prawdopodobnym, jak już wspomniałam, również analiza architektoniczna.

Kompleks oksywski składał się (w wersji skończonej) z kilkunastu budynków, wzniesionych w dwóch zasadniczych etapach budowlanych. Najważniejszym i najszybciej oddanym do użytku (w 1926 r.) był gmach Dowództwa Floty, stanowiący zarazem główną dominantę założenia. Zespół koszar, docelowo złożony z hali jadalni (od zachodu) i trzech budynków koszarowych, powstawał stopniowo, a w pierwszym etapie, do 1926 r., wzniesiono budynek jadalni i południowy koszarowy. Wtedy też powstał pierwszy podwójny dom dla podoficerów (zachodni) oraz niewielki dom oficerski tuż za nim. W drugim etapie, finansowanym już ze środków Funduszu Kwaterunku Wojskowego, po 1927 r. wystawiono drugi podwójny dom dla podoficerów, dwa domy dla oficerów i dom dowódcy, nazywany willą Unruga, bo admirał Józef Unrug, pełniący funkcję dowódcy Floty od 1925 do 1939 r., i jego rodzina byli jej jedynymi 
Małgorzata Omilanowska mieszkańcami. W skład kompleksu wchodził też budynek bramny, zespół stajni, wozowni i magazynów, łaźnia i dom adiutantury. Całość ukończono do $1931 \mathrm{r}$.

Dla przybywających do zespołu oksywskiego budynkiem identyfikowanym jako pierwszy z zespołem gmachów Marynarki Wojennej był i jest do dzisiaj budynek bramny (il. 2) ${ }^{16}$. Ma niezwykłą formę, został wzniesiony na odcinku łuku i stwarza wrażenie masywnego, prostego monolitu, przeprutego jedynie trzema identycznymi przelotami bramnymi zamkniętymi półkoliście, ozdobionego dwiema prostokątnymi, obramionymi niszami pomiędzy nimi, wyżej zaś czterema maleńkimi prostokątnymi okienkami przypominającymi strzelnice i płaskorzeźbą orła na osi. Od strony dziedzińca wprowadzono więcej niewielkich, okienek, które zdradzają, że budynek ma w istocie trzy kondygnacje (il. 3). Pomieszczenia wartowni dostępne są za drzwiami rozmieszczonymi w przelotach bramnych. Budynek jest zwarty, a wrażenie monumentalności podkreśla powściągliwa dekoracja: ledwo zarysowane poziome podziały gzymsami pod-i nadokiennymi oraz wydzielającym pas z mottem, boniowane dolne partie narożników i obłożone ciosami granitu cokoły naroży przelotów bramnych, a także obramienia nisz w postaci par półkolumn w okowach, zwieńczonych trójkątnymi naczółkami.

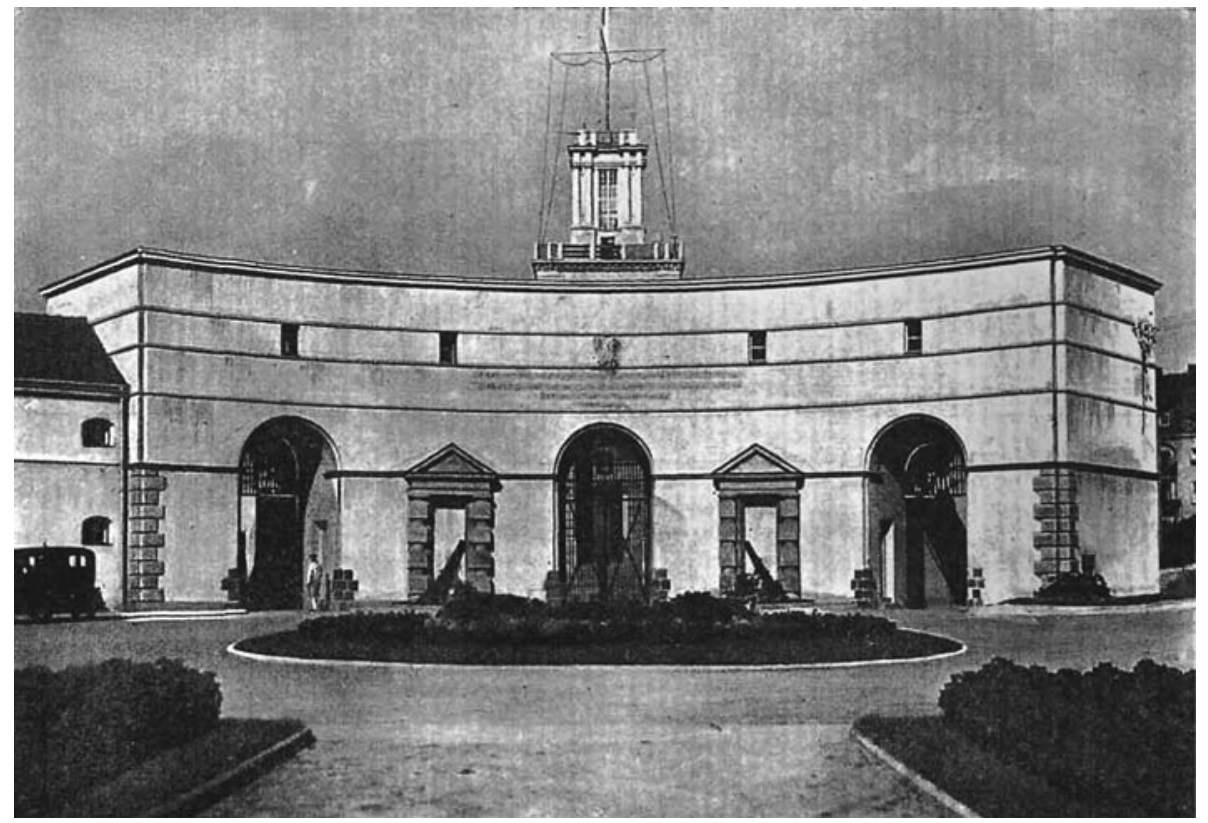

Il. 2. Gdynia, brama główna prowadząca do zespołu Dowództwa Floty i koszar Marynarki Wojennej na Oksywiu, proj. Marian Lalewicz, repr. za: „Architektura i Budownictwo” 1933, nr 10-12, s. 333, il. 34 


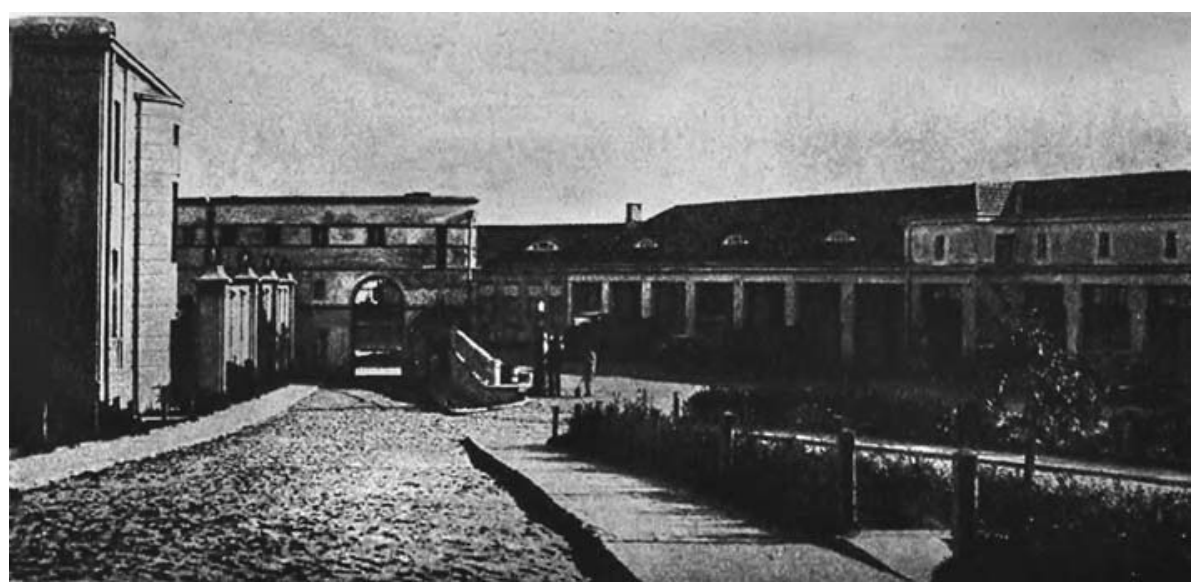

Gdyńska architectura militaris...

Il. 3. Gdynia, brama główna i budynki gospodarcze (po prawej) oraz gmach Dowództwa Floty na Oksywiu (po lewej), proj. Marian Lalewicz, repr. za: „Architektura i Budownictwo” 1933, nr $10-12$, s. 373 , il. 136

Całość wieńczy prosty, pozbawiony dekoracji mur niskiej attyki kryjącej płaski dach. Przeloty bramne zamykane były kutymi kratami.

Budynek bramny na Oksywiu nie ma bezpośrednich analogii w architekturze europejskiej, choć oczywiście w ogólnym zarysie przypomina zwielokrotniony łuk triumfalny, a bramy z triadą identycznej wysokości przelotów zdarzały się, ale nieczęsto, zwłaszcza w architekturze pierwszej połowy XIX w., że wymienię chociażby Bramę Iwanowską w Cytadeli Warszawskiej (ob. Brama Straceń) czy Bramę Brzeską w twierdzy w Brześciu Litewskim, obie z przełomu czwartej i piątej dekady XIX w. Oglądając ten gmach, nie sposób jednak oprzeć się skojarzeniom, czy raczej wspomnieniom projektów architektów nurtu francuskiego klasycyzmu rewolucyjnego, a zwłaszcza Claude’a-Nicolasa Ledoux i jego rogatek paryskich. Zaznaczam, że nie chodzi mi o podobieństwa formalne, ale raczej o podobny sposób myślenia, komponowania, gry masami gładkich murów i oszczędnymi dekoracjami operującymi wydatnym boniowaniem, przede wszystkim boniowanymi „kolumnami w okowach”.

Centralnym gmachem założenia zamykającym główną oś jest siedziba Dowództwa Floty, której projekt powstał w kwietniu 1924 r. ${ }^{17}$ Budowę ukończono latem i już w sierpniu $1926 \mathrm{r}$. budynek oddano do użytku ${ }^{18}$. Plan zakładał budowę piętrowego, rozłożystego, symetrycznie zakomponowanego gmachu, na rzucie zbliżonym do położonej litery $\mathrm{H}$, podporządkowanego osiowej wieży (il. 4). Piętrowy korpus frontowy, zwrócony fasadą ku południu, $\mathrm{z}$ wydatnym środkowym ryzalitem poprzedzonym wielkoporządkowym czterofilarowym

17 Projekt Marynarka Wojenna, Dom Dowództwa Floty Oksywie.

18 Nowa siedziba D-twa Floty Wojennej, „Morze” 1926, nr 8, s. 13; Kronika Gdyńska, „Morze” 1926, nr 11, s. 11; „Architektura i Budownictwo” 1933, nr 10-12, s. 331, il. 31, s. 332, il. 32; Por. też Sołtysik, Gdynia, miasto dwudziestolecia..., s. 68-69. 


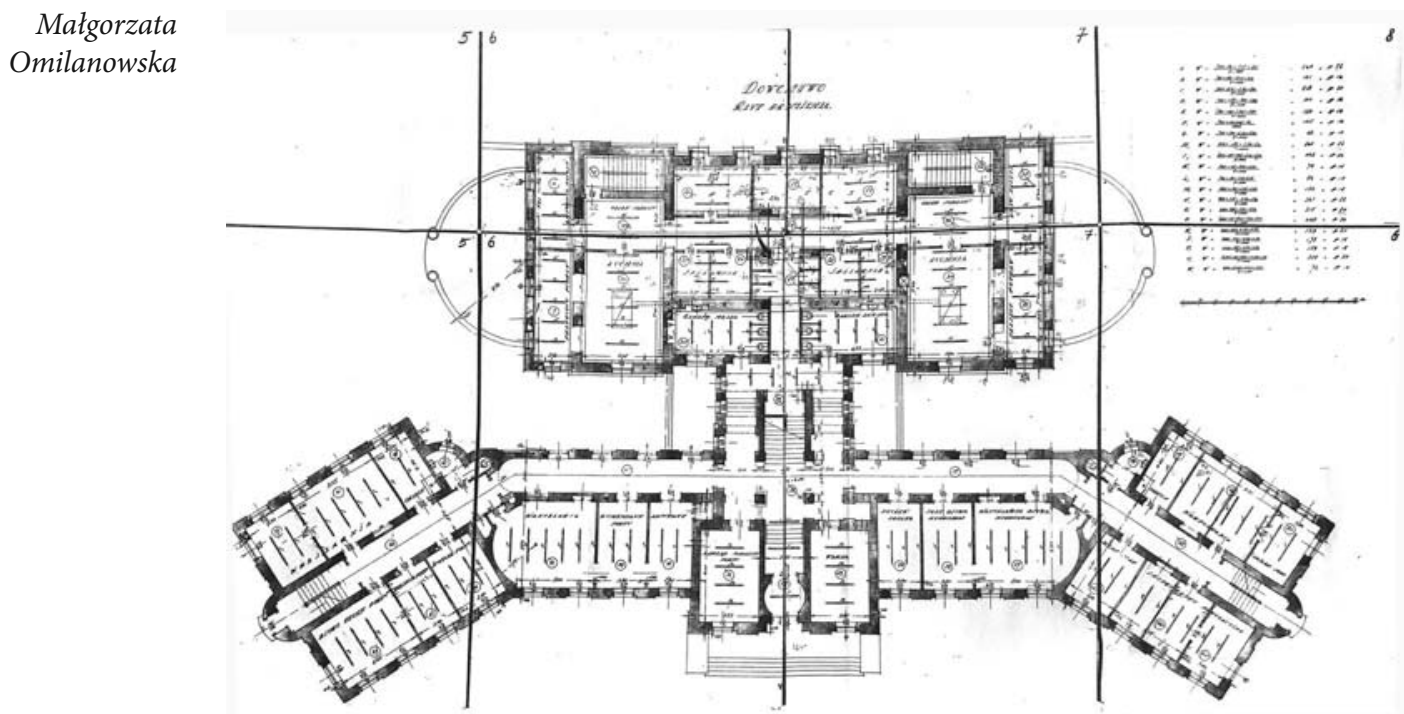

Il. 4. Projekt gmachu Dowództwa Floty na Oksywiu w Gdyni, rzut przyziemia, proj. Marian Lalewicz, kwiecień 1924, archiwum Rejonowego Zarządu Infrastruktury w Gdyni

portykiem, był poszerzony o parę skrzydeł ustawionych nieco skośnie, pod rozwartym kątem ku frontowi. Od północy powstał drugi korpus, zespolony niewielkim, prostopadle ustawionym łącznikiem. Budowla została rozplanowana na stoku, co spowodowało, że korpus frontowy położony jest pół kondygnacji niżej niż korpus tylny. Gmach miał zasadniczo dwie kondygnacje właściwe, użytkowe kondygnacje suteren i poddasza, ale korpus tylny był nadbudowany o trzecią kondygnację w skrajnych osiach, a korpus frontowy o czworoboczną wieżę obserwacyjną nad tylnym traktem.

Funkcjonalnie rozplanowane wnętrza w układach korytarzowych zostały podporządkowane wymagającemu programowi użytkowemu. Korpus frontowy przeznaczono na gabinety dowództwa i obsługujących kancelarii oraz salę konferencyjną, w skrzydłach bocznych rozmieszczono służby pomocnicze - nawigacyjne, kartograficzne, kreślarskie i szkoleniowe, w korpusie tylnym znalazło się zaś kasyno z jadalnią i czytelnią oraz salą bilardową, a w podziemiach - zaplecze kuchenne. W wieży usytuowano obserwatorium oraz pomieszczenia łączności.

Gmach był utrzymany w zmodernizowanych formach historycznych $\mathrm{z}$ dominacją klasycyzmu (il. 5). Zróżnicowaną bryłę kryły wielospadowe, dość wysokie dachy. Elewacje rytmizowane były lizenami, a najważniejsze partie - filary portyku głównego, portale, narożniki, ryzality i boczne klatki schodowe - boniowane. Projekt przewidywał bardzo skromny detal i ornamenty ograniczone do kluczy okien parteru, panopliów ujmujących okno nad wejściem głównym, płaskorzeźby $\mathrm{z}$ herbem w tympanonie trójkątnego naczółka portyku głównego i wolutowych zwieńczeń nad oknami mezzanina w korpusie tylnym. Jedynie wieżę obserwacyjną potraktowano bardziej dekoracyjnie, jej wyższą, 


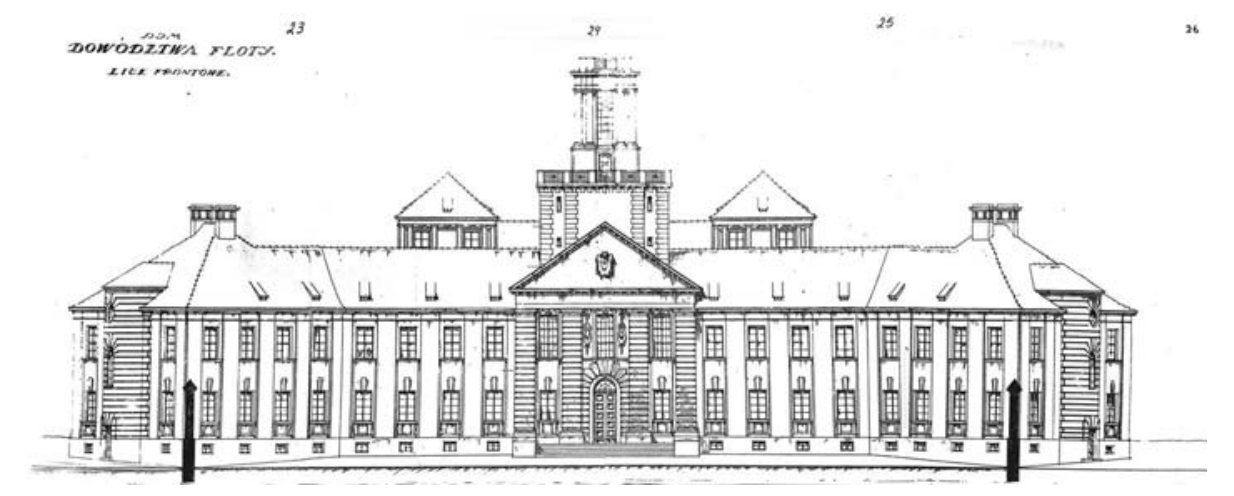

Gdyńska architectura militaris..

Il. 5. Projekt gmachu Dowództwa Floty na Oksywiu w Gdyni, fasada, proj. Marian Lalewicz, kwiecień 1924, archiwum Rejonowego Zarządu Infrastruktury w Gdyni

wieńczącą kondygnację ujęly pary jońskich kolumn w narożach oraz kule na ich osi na attyce wieńczącej. Trapezowy dziedziniec przed gmachem Dowództwa Floty został wydzielony murami odgradzającymi go od dróg wiodących do koszar i domów oficerskich.

W przypadku tego projektu trudno precyzyjnie wskazać źródło inspiracji, bowiem szerokie, symetryczne struktury wzbogacone ryzalitami i podporządkowane osiowo ustawionej wieży były charakterystyczne dla całej architektury nowożytnej i nowoczesnej, wznoszonej na potrzeby np. władz miejskich. Podobną strukturę ma też budynek Kunstkamery w Peteresburgu przy Nabrzeżu Uniwersyteckim 3, nota bene wzniesiony idealnie na osi siedziby Admiralicji, tyle że na Wyspie Wasiliewskiej. Jak zauważyła już Pakizer ${ }^{19}$, tego rodzaju strukturę ma również petersburski gmach urzędów miejskich przy Prospekcie Kronwerkskim 49, wzniesiony według projektu z $1910 \mathrm{r}$. autorstwa Polaka działającego w Petersburgu, Mariana Peretiatkowicza, ale $\mathrm{w}$ początkowej fazie projektowania

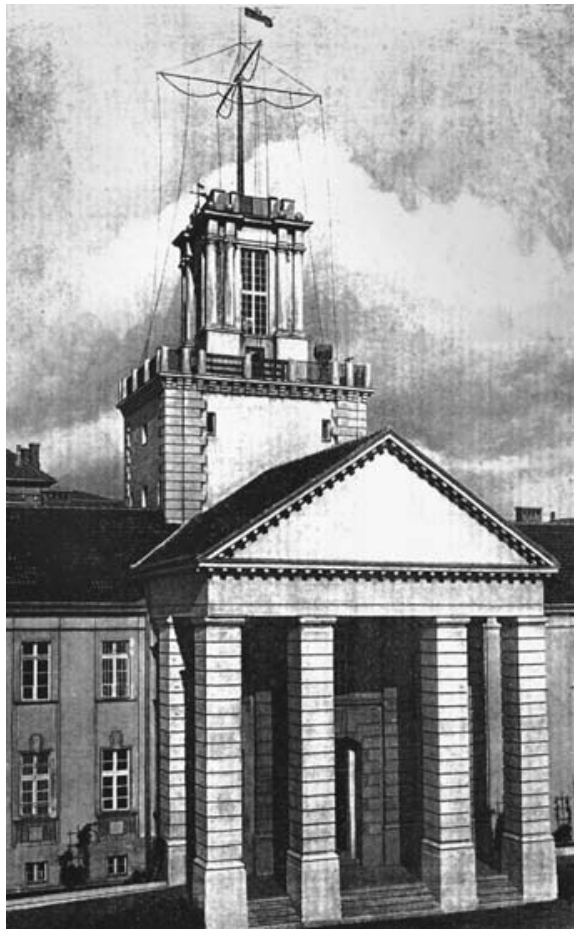

Il. 6. Gdynia, gmach Dowództwa Floty na Oksywiu, proj. Marian Lalewicz, repr. za: „Architektura i Budownictwo” 1933, nr 10-12, s. 331 , il. 31

19 Pakizer, Architektura budynków koszarowych..., s. 45. 
Małgorzata Omilanowska $\mathrm{z}$ udziałem Lalewicza ${ }^{20}$. Natomiast wielkoporządkowy, czterofilarowy, boniowany portyk zwieńczony trójkątnie (il. 6) nieodparcie nasuwa skojarzenia $\mathrm{z}$ rozwiązaniami zastosowanymi przez Ledoux w kilku projektach rogatek paryskich.

W założeniu oksywskim lewa droga prowadząca od zachodniego przelotu bramnego rozwidla się; na wprost wiedzie do domów podoficerskich, a na lewo ku zespołowi koszar Marynarki Wojennej. Od lewej ograniczał ją wzniesiony w latach 1927-1929 ciąg parterowych stajni, wozowni i magazynów o horyzontalnej bryle urozmaiconej ryzalitami ${ }^{21}$, zakończony od zachodu budynkiem na rzucie zbliżonym do litery T, mieszczącym łaźnię. Symetryczna bryła tego budynku składała się z parterowego, podłużnego korpusu z parterową poprzecznie ustawioną halą od północy i parą piętrowych, krótkich, tylnych skrzydeł, dostawionych lekko pod kątem i połączonych od południa wyoblonym bastejowo ryzalitem. Od strony koszar budynek otwierał się dużymi, półkoliście zamkniętymi oknami, ale od południa, czyli od zewnątrz, robił wrażenie założenia obronnego ponacinanego maleńkimi okienkami.

Czworobok koszar był wyznaczony od wschodu budynkiem jadalni w postaci wzniesionej na prostokątnym planie obszernej hali, krytej wysokim, łamanym dachem, $\mathrm{z}$ ciągami niskich pomieszczeń wzdłuż dłuższych boków i alkierzowymi dobudówkami w narożach (il. 7) ${ }^{22}$. Elewacje, zróżnicowane płytkimi wnękami, zamkniętymi łukami i boniowanymi narożnikami, były podporządkowane dominancie fasady od zachodu, $\mathrm{z}$ wielkoporządkowym wgłębnym portykiem ujętym parą boniowanych filarów, z parą kolumn o boniowanych dolnych

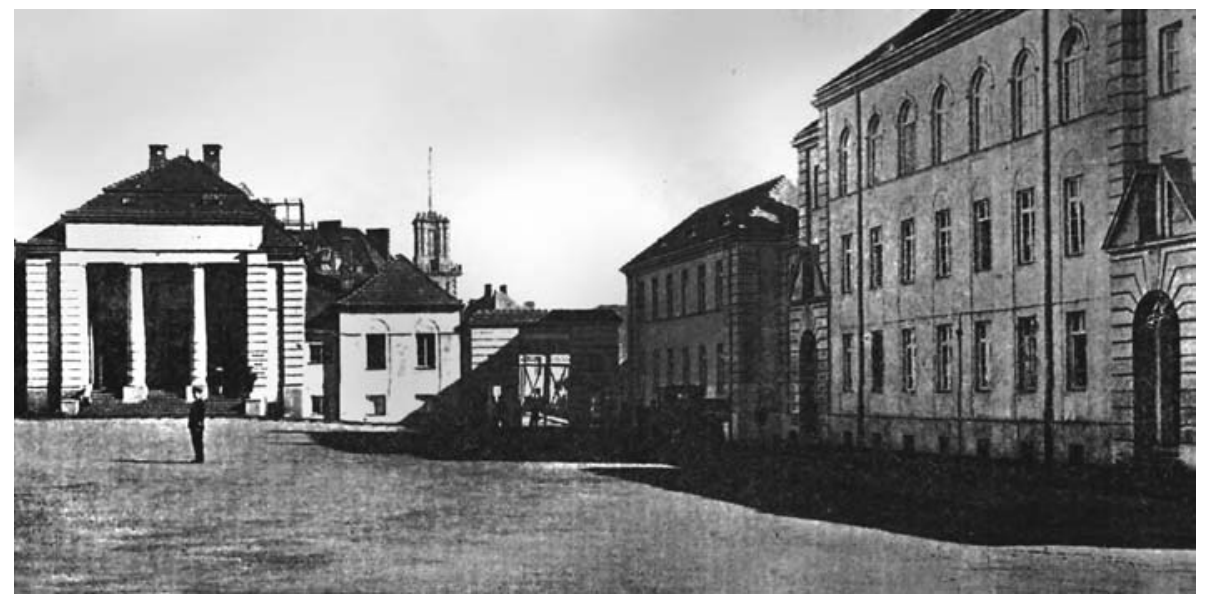

Il. 7. Gdynia, budynek jadalni (po lewej) i południowy budynek koszar (po prawej) w zespole Marynarki Wojennej na Oksywiu, proj. Marian Lalewicz, repr. za: „Architektura i Budownictwo" 1933, nr 10-12, s. 332, il. 32

20 Boris Kirikow, Architektura pietiersburgskogo moderna. Obszczestwiennyje zdanija. Kniga Wtaraja, Sankt Petersburg 2019, s. 336-345.

${ }^{21}$ "Architektura i Budownictwo” 1933, nr 10-12, s. 373, il. 136.

22 Ibidem, s. 332, il. 32. 
partiach trzonów, dźwigających wieńczący odcinek prostej attyki. Portyk ten przywołuje na myśl główne wejście do salin Ledoux, choć tam założenie jest znacznie bogatsze, oparte bowiem na sześciu podporach.

Trzy wielkie budynki koszarowe tego zespołu są do siebie bardzo podobne, choć nie identyczne. Wszystkie mają podobne dekoracje elewacji w postaci półkoliście zamkniętych płytkich wnęk ujmujących piony okien i boniowania w partiach narożników i lizen, a także ceramiczne czteropołaciowe dachy z powiekami. $\mathrm{W}$ pierwszym etapie, oprócz jadalni, powstał budynek południowy przeznaczony na koszary dla marynarzy (il. 7) ${ }^{23}$. Składał się z trzypiętrowego korpusu głównego, pary dwupiętrowych skrzydeł bocznych w osi podłużnej korpusu, nieco wysuniętych względem jego lica frontowego, i pary dwupiętrowych skrzydeł prostopadłych do korpusu, przylegających do jego tylnych narożników. Korpus od tyłu wzbogacono o parę mieszczących klatki schodowe wydatnych ryzalitów na półkolistym rzucie. Dekorację elewacji, oprócz wspomnianych elementów, stanowiły dwa efektowne portale ulokowane w miejscu połączenia korpusu ze skrzydłami bocznymi. Portale te to boniowane obramienia półkoliście zamkniętych otworów drzwiowych, zwieńczone wysokimi, przerwanymi, trójkątnymi naczółkami.

Niemal identyczny kształt uzyskał budynek zachodni, ukończony w $1930 \mathrm{r}$. Ma analogiczny rzut, a więc składa się z wydzielonego korpusu i dwóch par skrzydeł bocznych, tyle że ma trzy pełne kondygnacje wyniesione na wysokiej suterenie, a partia wejścia głównego zyskała rozwiązanie w formie trójosiowego pseudoryzalitu opiętego boniowanymi lizenami, z triadą prostokątnych drzwi i szeroką, trójosiową wystawką w dachu na osi (il. 8) ${ }^{24}$. Budynek północny, zbudowany nieco później, oddany do użytku w 1933 r., jest niemal identyczny (il. 9) ${ }^{25}$. Pozbawione ozdobnego obramienia wejście główne Lalewicz umieścił na osi środkowej, cofając ją nieco, podwyższając o kondygnację (na której później umieszczono zegar słoneczny) i zamykając prosto. Dzisiejszy kształt tego zespołu odbiega od pierwotnego, już po wojnie połączono wszystkie trzy budynki dodatkowymi skrzydłami łącznikowymi, podwyższono dwukondygnacyjne skrzydła budynku południowego, a pomiędzy tylne skrzydła budynku zachodniego wstawiono aulę zwieńczoną kopułą.

Ważnym dopełnieniem zespołu na Oksywiu, ze względu na odległość od miasta, były budynki mieszkalne dla kadry oficerskiej. Już w pierwszym etapie rozpoczęto budowę podwójnego domu dla podoficerów, ulokowanego na osi zachodniej drogi wiodącej od bramy, i niewielkiego domu oficerskiego za nim. Natomiast po utworzeniu Funduszu Kwaterunku Wojskowego, rozkazem Piłsudskiego z 25 lipca 1927 r., organizacja ta dokończyła budowę pierwszego domu i rozpoczęła drugi etap, który objął wzniesienie drugiego domu podoficerskiego, dwóch domów oficerskich i domu dowódcy. Planowano zbudowanie jeszcze dwóch dalszych

Ibidem.

Ibidem, s. 373, il. 134.

25 Ibidem, s. 373, il. 135. 


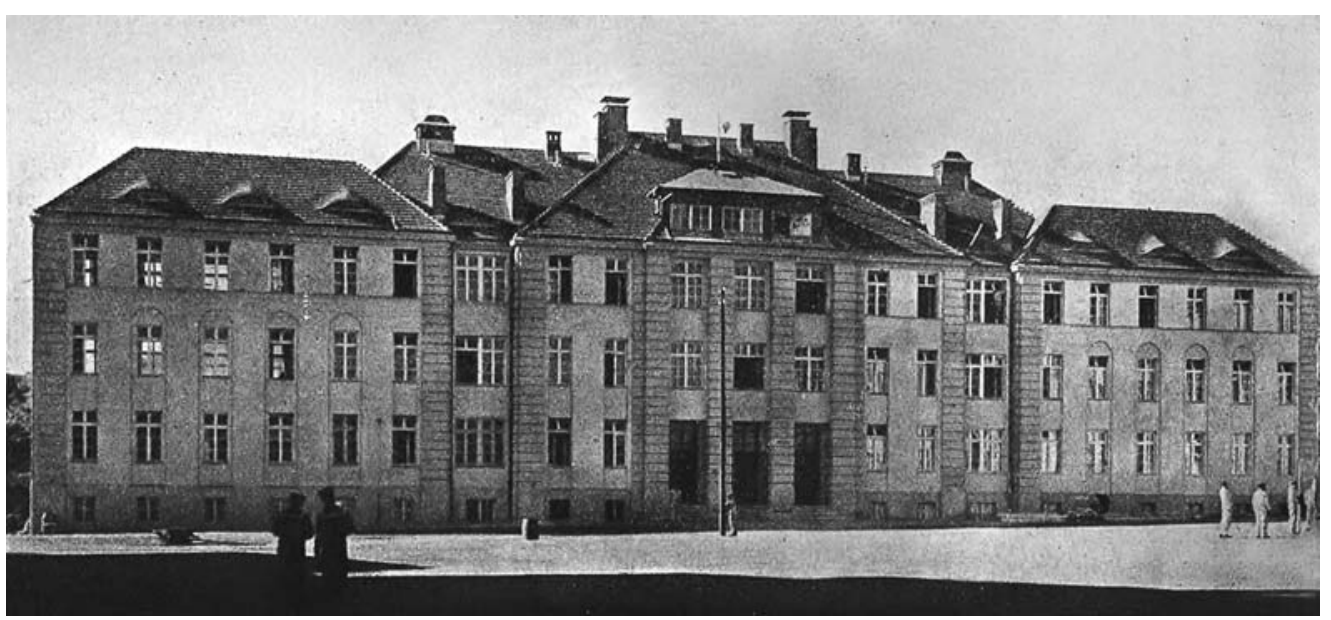

Il. 8. Gdynia, zachodni budynek koszar w zespole Marynarki Wojennej na Oksywiu, proj. Marian Lalewicz, repr. za: „Architektura i Budownictwo” 1933, nr 10-12, s. 373, il. 134

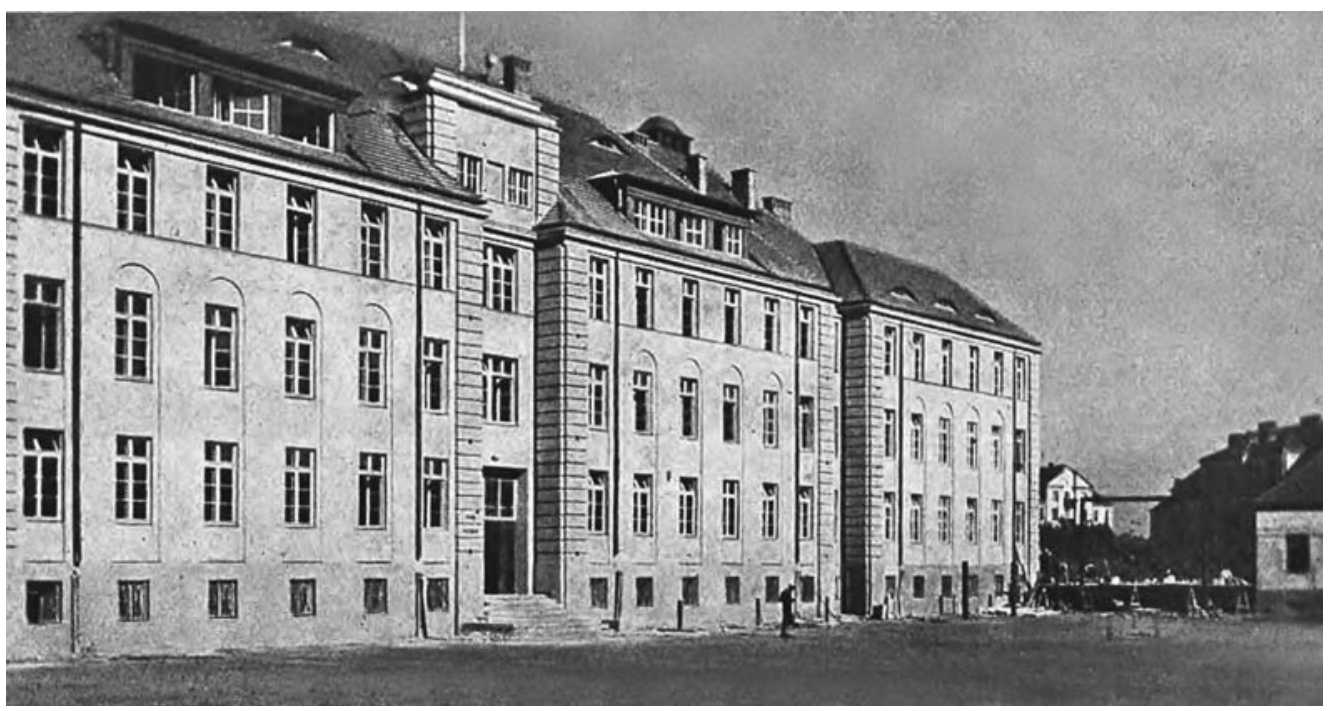

Il. 9. Gdynia, północny budynek koszar w zespole Marynarki Wojennej na Oksywiu, proj. Marian Lalewicz, repr. za: „Architektura i Budownictwo” 1933, nr 10-12, s. 373, il. 135 
domów oficerskich, ale do realizacji tego pomysłu nie doszło ${ }^{26}$. Ponadto w samej Gdyni podjęto budowę (według projektu Lalewicza) jednego domu podoficerskiego (ulica Morska 67) i jednego oficerskiego (ulica 10 Lutego 29).

Rozporządzeniem Rady Ministrów z 29 sierpnia 1927 r. określono wielkości mieszkań obowiązujące w nowo projektowanych budynkach dla wojska, wznoszonych przez Fundusz Kwaterunku Wojskowego: niżsi podoficerowie mieli prawo do pokoju z mieszkalną kuchnią o powierzchni $20 \mathrm{~m}^{2}$, starsi podoficerowie do dwóch pokojów z kuchnią o powierzchni $50 \mathrm{~m}^{2}$, młodsi oficerowie żonaci (do kapitana włącznie) do trzech pokojów z kuchnią i łazienką o powierzchni $90 \mathrm{~m}^{2}$, a majorzy i pułkownicy do mieszkania czteropokojowego o powierzchni $120 \mathrm{~m}^{227}$.

Budowy podjęte z inicjatywy FKW miały podobny harmonogram: zaprojektowano je pod koniec 1927 lub na początku 1928 r., prace rozpoczęto w sezonie budowlanym 1928 r. i kontynuowano po przerwie zimowej (zima 1928/1929 była wyjątkowo ciężka w Polsce i nie pozwalała na prowadzenie robót budowlanych), budowę ukończono w 1929 r. bądź w pierwszej połowie 1930 r. Żaden z budynków na Oksywiu, wznoszonych przez FKW, do wydania opracowania - do października 1930 r. - nie był formalnie skolaudowany, czyli nie był odebrany od wykonawcy, ale faktycznie zasiedlono już wówczas pierwszy dom podoficerski, domy oficerskie i willę Unruga ${ }^{28}$. Uroczystość poświęcenia domów mieszkalnych, zarówno tych na Oksywiu, jak i w samej Gdyni (o których poniżej), a także gmachów koszarowych i szkolnych odbyła się 8 grudnia $1930 \mathrm{r}^{29}$

Zachodni, najstarszy dom podoficerski, oddany do użytku już w 1925 lub na początku 1926 r. (il. 10), składa się z dwóch dwupiętrowych, sześcioosiowych bloków mieszkalnych, ustawionych względem siebie pod szeroko rozwartym kątem, zespolonych trójosiowym łącznikiem z wysoką, obejmującą dwie kondygnacje, półkoliście zamkniętą bramą przejazdową na osi ${ }^{30}$. Od południa każdy z bloków przecina oś loggii, a elewacje urozmaicają boniowane lizeny opinające łącznik. W elewacjach północnych rozmieszczono portale wejściowe ujęte boniowaniami i zwieńczone trójkątnymi, przerwanymi naczółkami, a bryły urozmaicono wyciągnięciem o jedną kondygnację wzwyż osi głównych i poszerzenie ich o rozbudowane wystawki, mieszczące mieszkania kawalerskie. Za domem podoficerskim powstał niewielki, piętrowy dom dla oficerów o symetrycznej kompozycji wzbogaconej ryzalitami środkowymi.

26 Sprawozdanie Funduszu Kwaterunku Wojskowego 1927-1937, Warszawa 1938, s. 62.

27 Domy mieszkalne Funduszu Kwaterunku Wojskowego. Sprawozdanie 1927-1930, Warszawa 1930, s. 25.

28 Ibidem, s. 126, 248.

29 Poświęcenie gmachów mieszkalnych marynarki w Gdyni, „Gazeta Polska” 1930, nr 337, s. 1.

30 "Architektura i Budownictwo" 1929, nr 2-3, s. 48, il. 11-12; Domy mieszkalne Funduszu..., s. 220; „Architektura i Budownictwo” 1933, nr 10-12, s. 333, il. 35. 


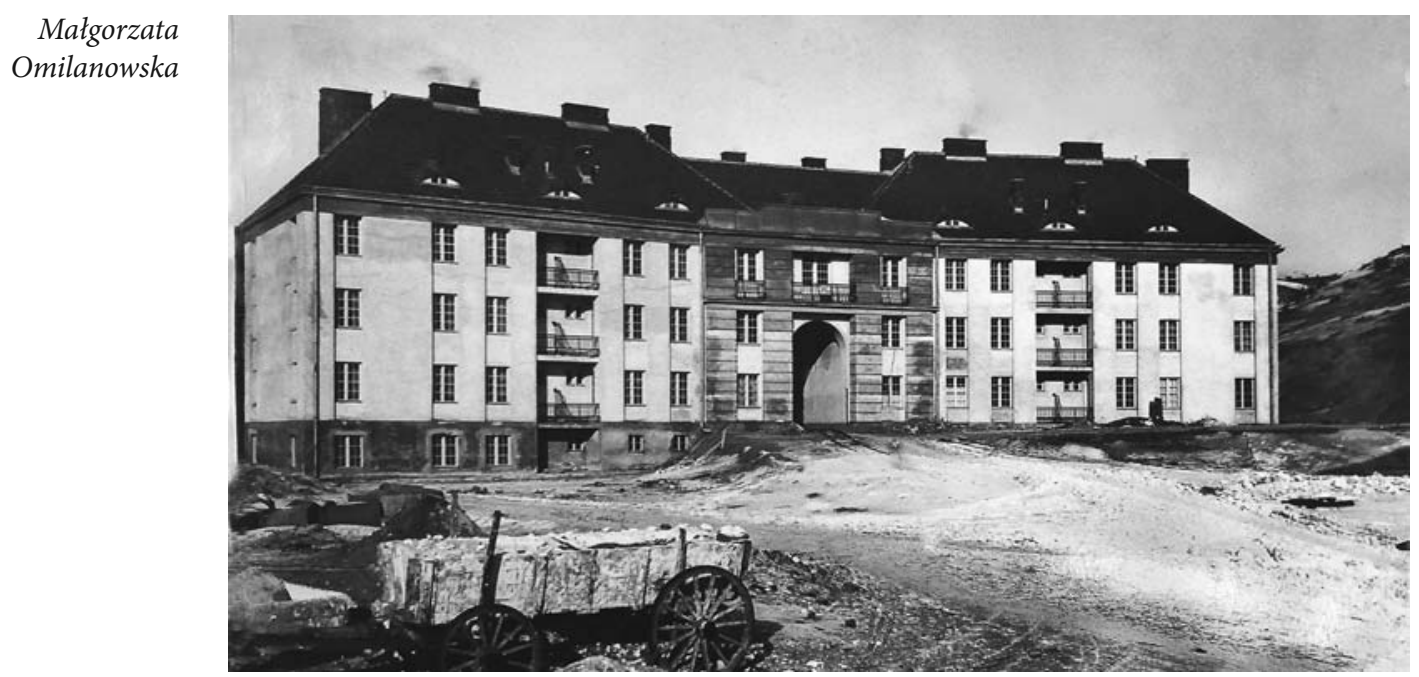

Il. 10. Gdynia, dom podoficerski (zachodni) w zespole koszar Marynarki Wojennej na Oksywiu, proj. Marian Lalewicz, repr. za: „Architektura i Budownictwo” 1929, nr 2-3, s. 47, il. 10

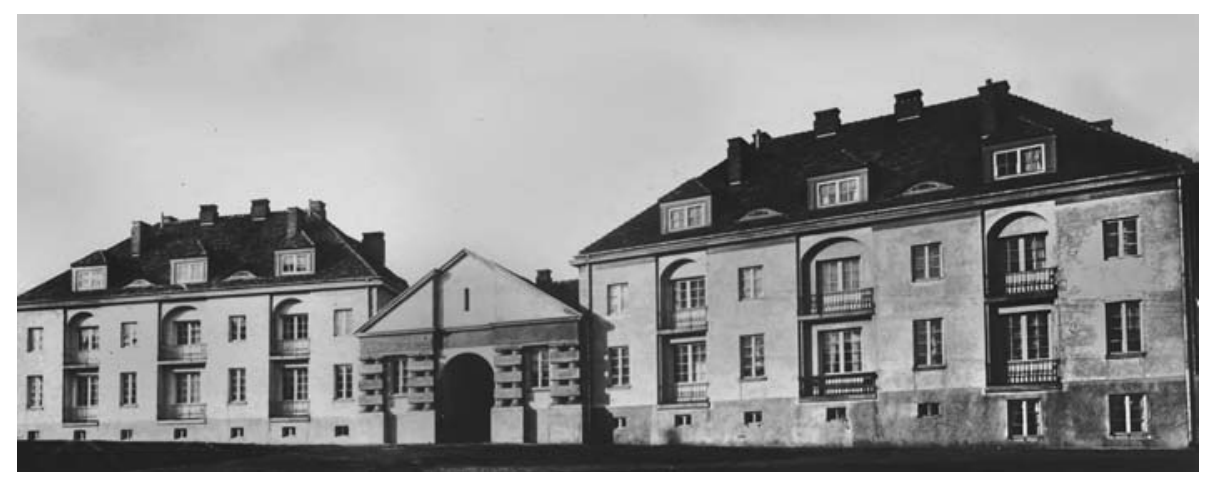

Il. 11. Gdynia, dom podoficerski (wschodni) w zespole koszar Marynarki Wojennej na Oksywiu, proj. Marian Lalewicz, fot. Narodowe Archiwum Cyfrowe w Warszawie, sygn. 1-W-1956-3

Wschodni budynek podoficerski znalazł się na osi prawej wschodniej drogi wiodącej od bramy głównej (il. 11) ${ }^{31}$. Został on zakomponowany analogicznie: też składa się z dwóch dwupiętrowych bloków zespolonych łącznikiem z wielkim przelotem bramnym, ale różni się $\mathrm{w}$ detalach. Siedmioosiowe elewacje południowe bloków zróżnicowane są łukowo zamkniętymi pionami wnęk z balkonami, a trójosiowy łącznik jest jednokondygnacyjny, opięty czterema parami kolumn w okowach i zwieńczony trójkątnie. Północne elewacje wzbogacono parami jednoosiowych ryzalitów na rzucie odcinka łuku mieszczących klatki schodowe i wejścia w boniowanych obramieniach. Wyróżnia je także dodatkowa

$31 \quad$ Ibidem, s. 332, il. 32. 
niska kondygnacja w partii środkowej mieszcząca małe kawalerki dla podoficerów bez rodzin. Związki z projektami Ledoux w przypadku tego budynku polegają na bliskim pokrewieństwie rozwiązania dekoracji bramy przelotowej i zastosowaniu par kolumn w okowach. Warto też wskazać na podobieństwa do Bramy Newskiej (Niewskije Worota) twierdzy Pietropawłowskiej w Petersburgu, gdzie użyto dwóch par kolumn w dolnych partiach opiętych boniowanymi okowami.

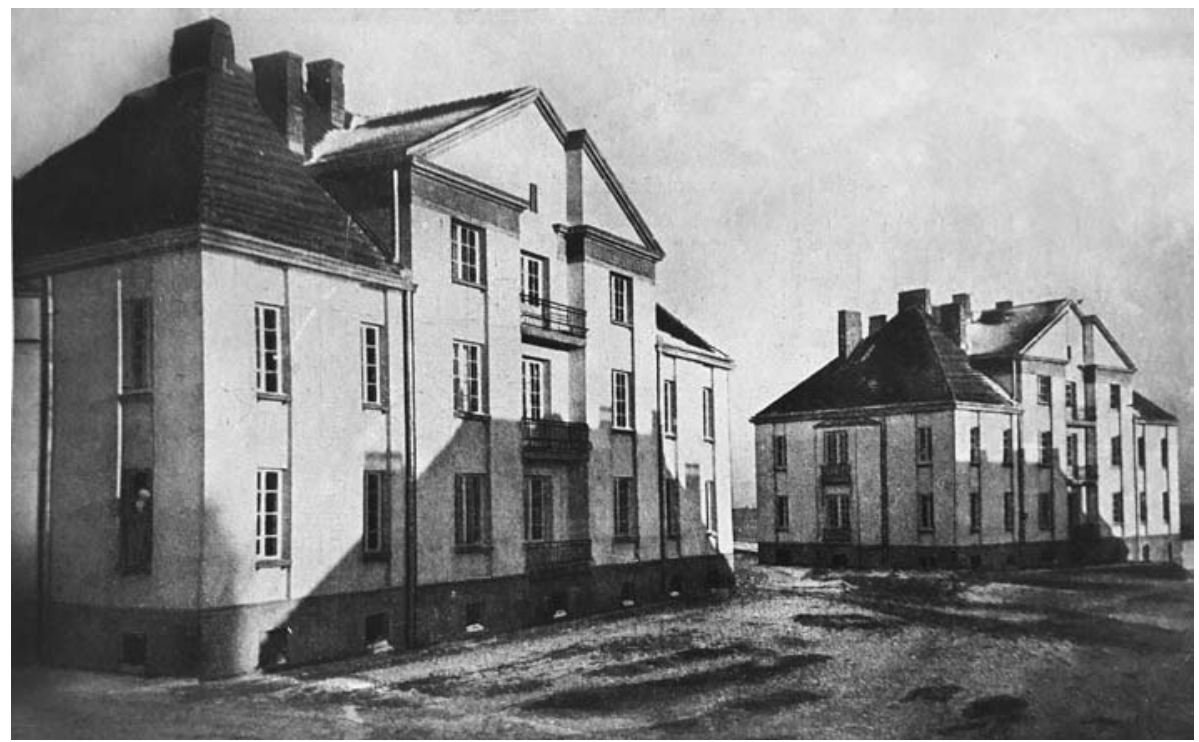

Il. 12. Gdynia, domy oficerskie w zespole koszar Marynarki Wojennej na Oksywiu, proj. Marian Lalewicz, repr. za: „Architektura i Budownictwo” 1929, nr 2-3, s. 47, il. 10

Droga wschodnia, po przejściu przez przelot bramny na osi wschodniego domu podoficerskiego, wspina się po prostej dalej na zbocze stoku i pozwala dotrzeć do pary położonych wyżej dwóch identycznych wielomieszkaniowych domów dla oficerów, zasiedlonych już w 1929 r. ${ }^{32}$ Każdy budynek jest piętrowy, z dwupiętrową częścią środkową zwieńczoną trójkątnie (il. 12). Symetrycznie zakomponowane, o elewacjach zrytmizowanych lizenami, kryte czterospadowymi dachami, wyróżnia jedynie nieco manierystyczny pomysł cofnięcia na całej wysokości środkowej osi, co powoduje, że trójkątne szczyty też mają partię środkową cofniętą względem bocznych. Północne elewacje urozmaicają jednoosiowe boniowane ryzality klatek schodowych.

Najwyżej położonym budynkiem części mieszkalnej, który można osiągnąć, podążając drogą wschodnią, jest dom dowódcy Floty - willa Unruga - ukończony w $1930 \mathrm{r}^{33}$ Ten piętrowy budynek, z pomieszczeniami dziennymi i reprezentacyjnymi

32 „Architektura i Budownictwo” 1929, nr 2-3, s. 47, il. 10.

33 Domy mieszkalne Funduszu..., s. 124-125; Sprawozdanie Funduszu..., s. 62; Sołtysik, Gdynia, miasto dwudziestolecia..., s. 67. 


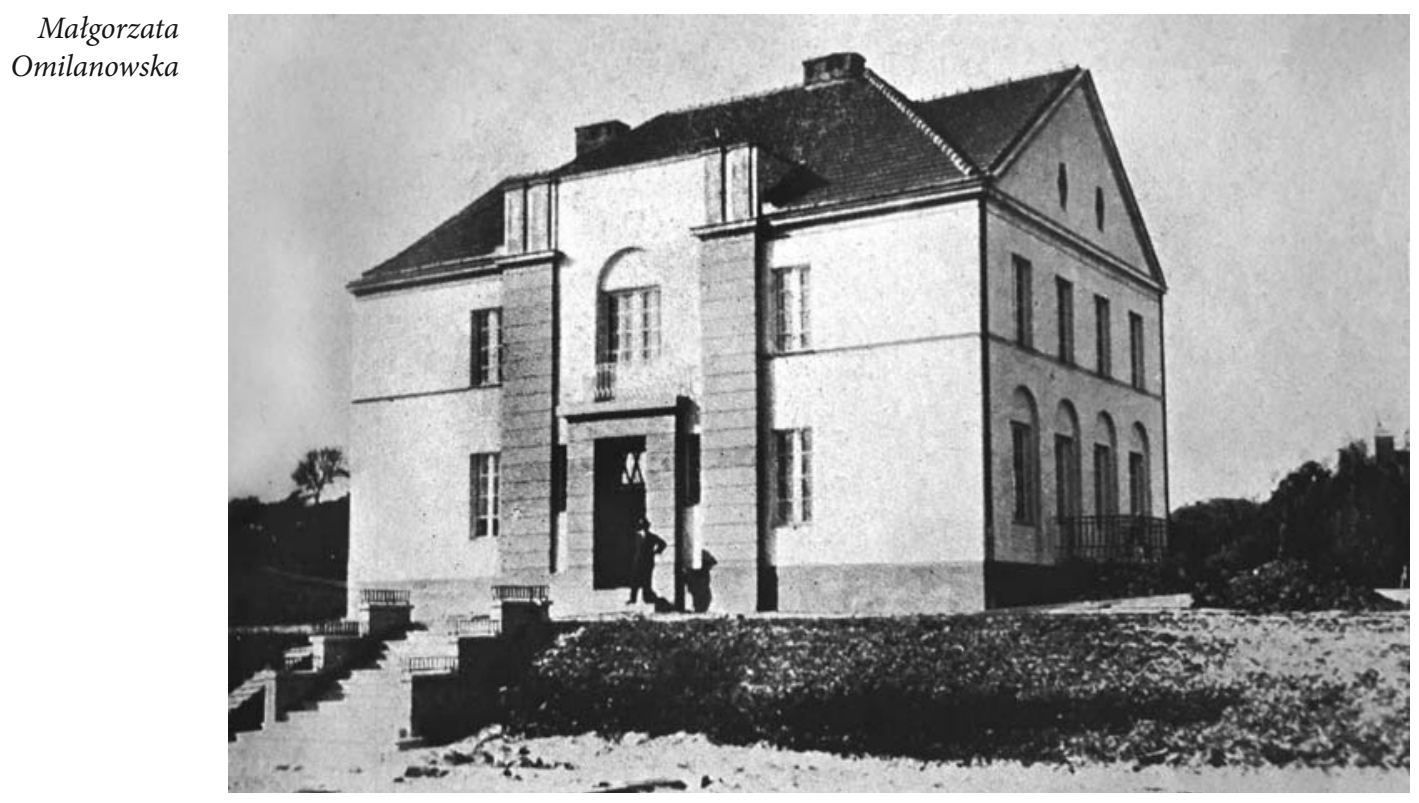

Il. 13. Gdynia, dom dowódcy Floty, tzw. willa Unruga, w zespole koszar Marynarki Wojennej na Oksywiu, proj. Marian Lalewicz, repr. za: Domy mieszkalne Funduszu. 1927-1930, s. 124

na parterze oraz sypialniami na piętrze, skomunikowanymi dwiema klatkami schodowymi, ma zadziwiająco skromną formę (il. 13). Wzniesiony na rzucie prostokąta, kryty czterospadowym dachem z dużymi, trójkątnymi wystawkami o szerokości szczytowych ścian ponad elewacjami bocznymi, jest niemal pozbawiony dekoracji. Para boniowanych lizen ujmuje środkową, nieco wyższą oś w fasadzie i elewacji północnej, gdzie na piętrze umieszczono balkony. Boniowane są także lizeny portalu głównego i parter elewacji bocznych, zrytmizowanych płytkimi arkadowymi niszami ujmującymi okna. Dom dowódcy Floty mieścił w sumie 13 izb, miał kubaturę $1823 \mathrm{~m}^{3}$, koszt metra sześciennego wyniósł $74.40 \mathrm{zł}$, a koszt izby 9.692 zł, co czyniło z niego najdroższą inwestycję FKW w Polsce ${ }^{34}$. Na zachód od willi Unruga stanął parterowy pawilon adiutantury.

W samej Gdyni, jak wspomniałam, Lalewicz zaprojektował dla FKW dom oficerski przy ulicy 10 Lutego 29, który wzniesiono w latach 1928-193035. Była to przyuliczna czteropiętrowa kamienica bez oficyn, z mieszkaniami także na parterze (il. 14). Mieściła 8 mieszkań (w sumie $30 \mathrm{izb}$ ) i była wyposażona $\mathrm{w}$ centralne ogrzewanie. Jedenastoosiowa fasada była zróżnicowana jedynie lekkim cofnięciem środkowej osi z balkonami, wyróżnieniem jej płytką wnęką zamkniętą łukiem i zwieńczeniem w formie prostej attyki. Balkony rozmieszczono także na trzeciej i dziewiątej osi. Skromną dekorację fasady stanowiło

34 Domy mieszkalne Funduszu..., s. 196.

35 Ibidem, s. 33, 122-123. 


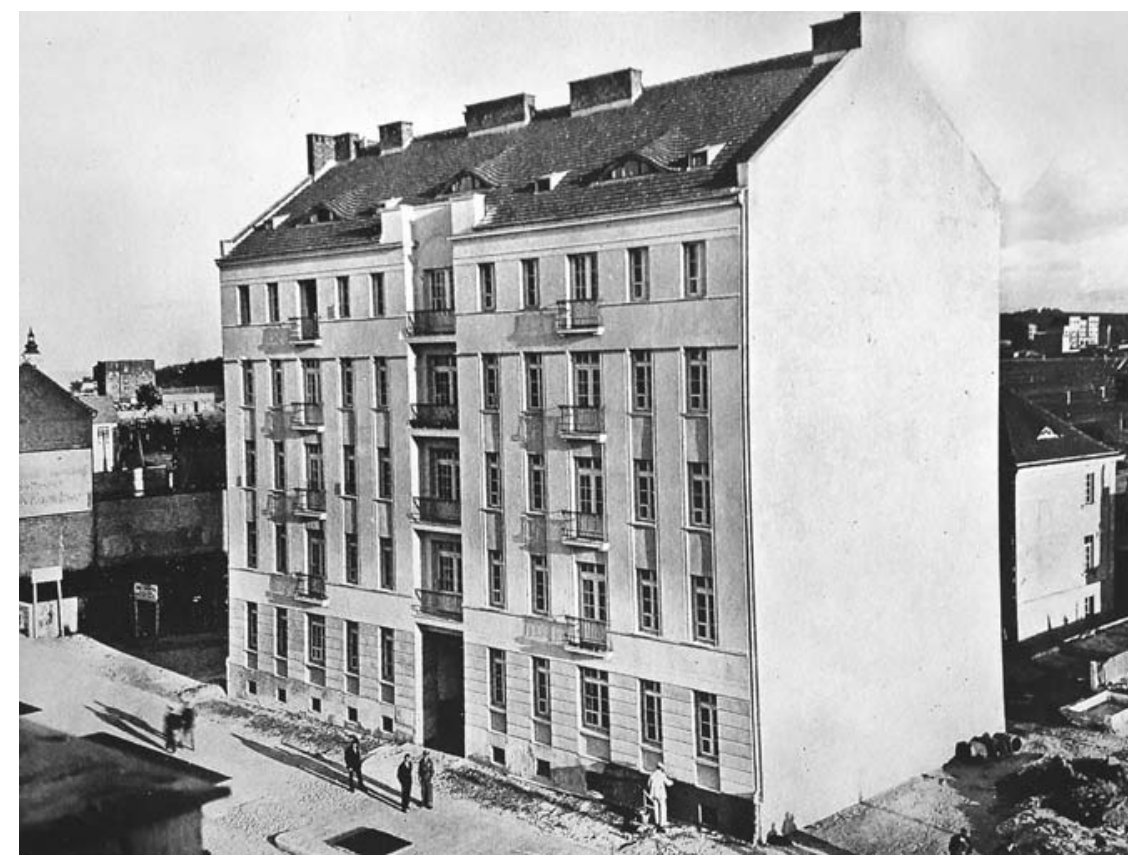

Gdyńska architectura militaris...

Il. 14. Gdynia, dom oficerski przy ulicy 10 Lutego 29, proj. Marian Lalewicz, repr. za: Domy mieszkalne Funduszu. 1927-1930, s. 122

boniowanie parteru i podziały pionowe w postaci lizen opinających drugą, trzecią i czwartą kondygnację oraz poziome pasy odcinające ostatnią kondygnację. Od podwórka bryłę wzbogacała para ryzalitów klatek schodowych i pion balkonów na osi środkowej. Kierownikiem budowy był inż. Zygmunt Horyd, a wykonawcą „Syndykat Techniczno-Budowlany”.

Lalewicz był też autorem projektu domu podoficerskiego FKW przy ulicy Gdańskiej (obecnie ulica Morska 67) ${ }^{36}$. Budynek wznoszono w latach 1928-1931 i nigdy nie zrealizowano w całości pierwotnego projektu (il. 15). Dom został zaprojektowany na rzucie szachownicy i miał się składać z pięciu połączonych ze sobą czteropiętrowych bloków - jeden miał zostać ustawiony po środku, a cztery pozostałe - łączyć się z nim narożnikami. Pierwotnie planowano, że trzy bloki będą przeznaczone na mieszkania podoficerskie, a jeden na mieszkania oficerskie. Zrealizowano jednak tylko część zaprojektowanego kompleksu - blok środkowy i parę wschodnią, w całości przeznaczając je na dwupokojowe mieszkania dla podoficerów - powstało łącznie 48 mieszkań. Także i ten zespół utrzymany był w powściągliwych formach - z różnicowaniem brył ograniczonym w blokach bocznych do lekkiego wycofania osi środkowych, zwieńczonych odcinkiem pełnej attyki, artykulacją elewacji w postaci lizen i pionów $\mathrm{z}$ balkonami oraz dekoracyjnym boniowanym portalem $\mathrm{w}$ płytkim

36 „Architektura i Budownictwo” 1929, nr 2-3, s. 49, il. 13-14; Domy mieszkalne Funduszu..., s. 120-121, 219. 


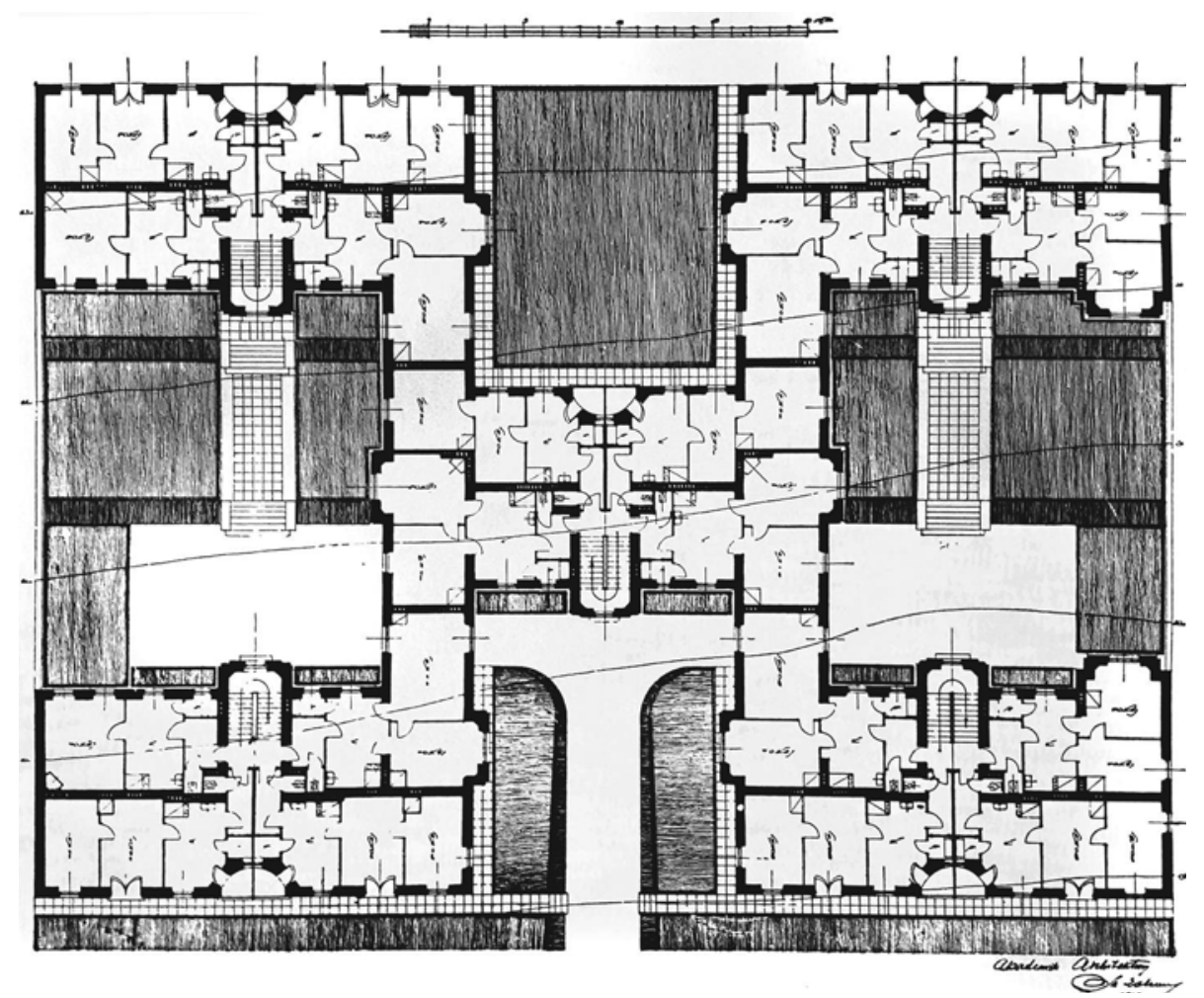

Il. 15. Projekt domu podoficerskiego w Gdyni przy ulicy Morskiej 67, rzut parteru, proj. Marian Lalewicz, repr. za: Domy mieszkalne Funduszu. 1927-1930, s. 120

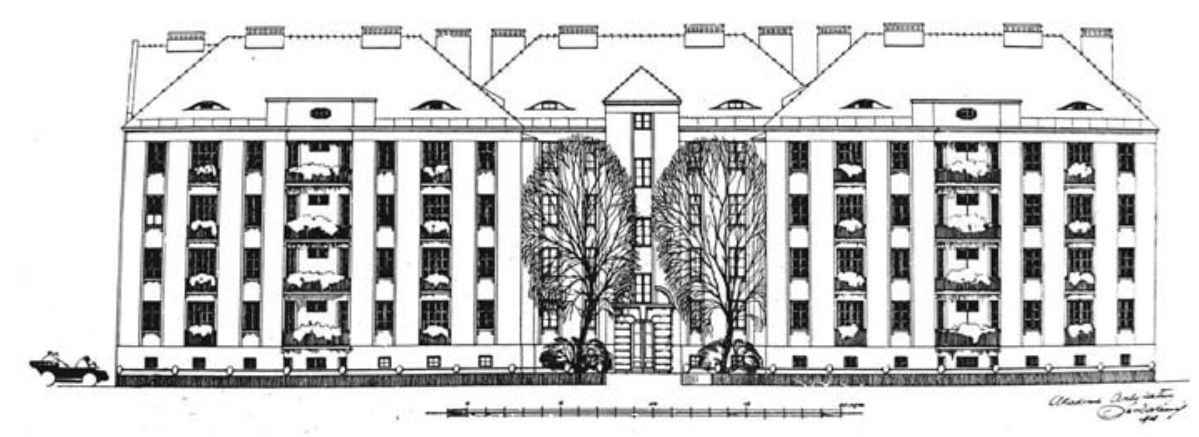

Il. 16. Projekt domu podoficerskiego w Gdyni przy ulicy Morskiej 67, fasada, proj. Marian Lalewicz, repr. za: Domy mieszkalne Funduszu. 1927-1930, s. 120 
ryzalicie na osi bloku środkowego (il. 16). W projekcie Lalewicz przewidział, że osie środkowe budynków bocznych będą półkoliście wklęsłe, co pozwoli na utworzenie wspólnych dla dwóch mieszkań loggii, ale w wersji realizacyjnej z tego rozwiązania zrezygnowano na rzecz prostej ściany z parami okien. Nie zrealizowano także neobarokowego, przerwanego naczółka nad portalem głównym.

W latach trzydziestych zespół oksywski Marynarki Wojennej został dopełniony jeszcze o dwie budowle: szpital i kościół garnizonowy. Gmach szpitala wzniesiono w latach 1930-1932 na stoku wzgórza ponad zespołem koszar i nieco na zachód od niego, przy ulicy Grudzińskiego $4^{37}$. Budynek o trzech kondygnacjach od południa (wysoka suterena, parter i piętro) i dwóch od północy, kryty płaskim dachem, zbudowano na rzucie wykorzystanym przez Lalewicza w projektach budynków koszarowych (il. 17). Składał się on z korpusu z wydatnym ryzalitem środkowym, pary wysuniętych, równoległych skrzydeł bocznych z obszernymi loggiami na obu wyższych kondygnacjach północno-wschodniego narożnika oraz pary krótkich prostopadłych skrzydeł przylegających do naroży korpusu od tyłu, czyli od północy (il. 18). Pod względem stylistycznym budynek szpitala różnił się już zasadniczo od rozwiązań z lat dwudziestych. Zyskał poziomą, wyrazistą artykulację w postaci klinkierowych pasów obiegających wszystkie elewacje i obejmujących okna; jedynie ryzalit frontowy otrzymał też klinkierową artykulację, ale lizenami, i wielkie przeszklenia ogromnych okien wypełniających w górnej kondygnacji całą przestrzeń pomiędzy nimi. Płaski dach, horyzontalna artykulacja, zastosowanie klinkieru i dużych przeszkleń wpisują już architekturę szpitala w nieawangardowy nurt modernizmu lat trzydziestych.

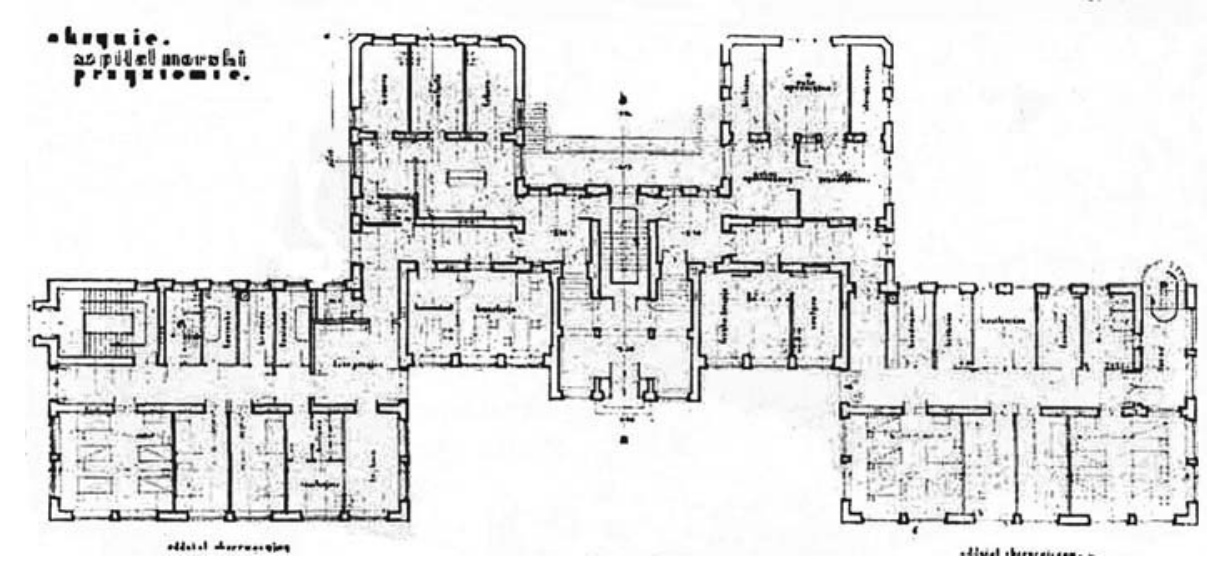

Il. 17. Projekt szpitala w zespole koszar Marynarki Wojennej, rzut parteru, proj. Marian Lalewicz, repr. za: „Architektura i Budownictwo” 1933, nr 10-12, s. 339, il. 49 


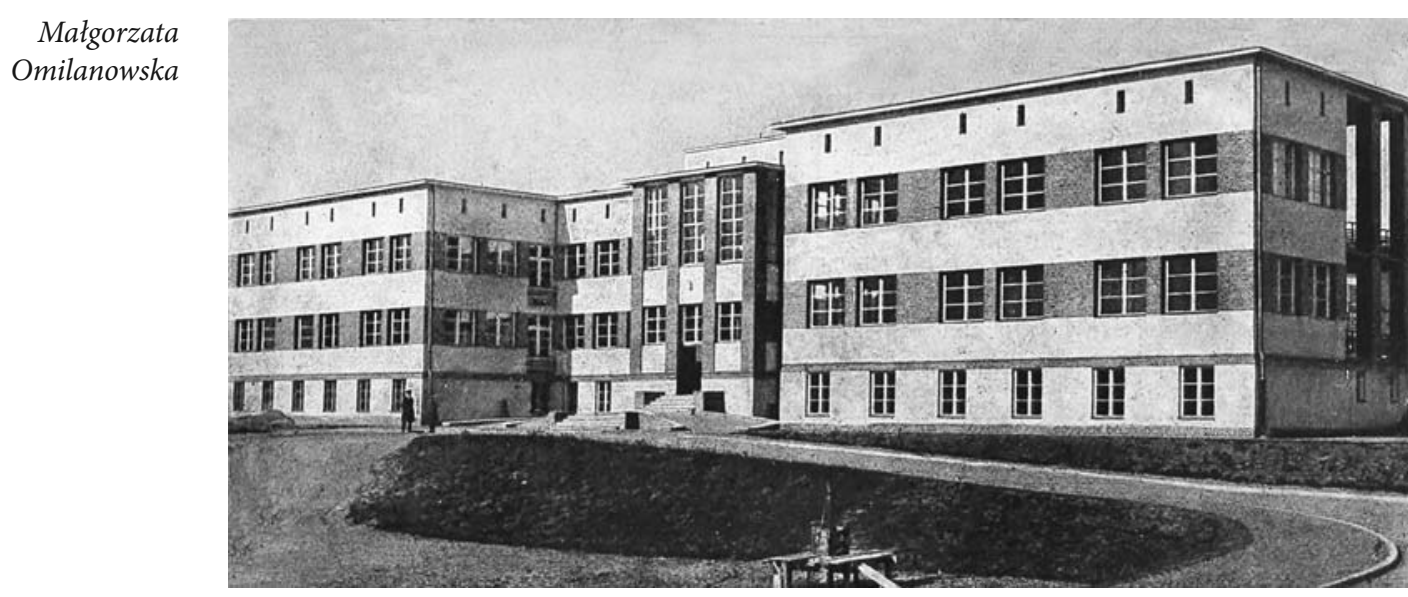

Il. 18. Gdynia, szpital w zespole koszar Marynarki Wojennej, proj. Marian Lalewicz, repr. za: „Architektura i Budownictwo” 1933, nr 10-12, s. 339, il. 47

Kościół Marynarki Wojennej pw. Matki Bożej Częstochowskiej przy ulicy inż. Jana Śmidowicza 47 został zaprojektowany w 1932 r., a jego realizacja była prowadzona od 1935 do 1939 r. (pierwszą mszę odprawiono w lipcu, tuż przed wybuchem wojny) ${ }^{38}$. Ma on tradycyjną strukturę trójnawowej bazyliki (w projekcie pseudobazyliki), z wyodrębnionym, niższym, zamkniętym prosto prezbiterium i przylegającą doń od zachodu kwadratową kaplicą krytą ośmiopołaciowym dachem (il. 19). Jego bryła nie jest już jednak tradycyjna. Nawy kryte są płaskimi żelbetowymi stropami wspartymi na gęsto rozstawionych smukłych filarach, a rytm elewacji wyznaczają równie gęste, pionowe podziały wyprowadzone w klinkierowych żebrach, z ogromnymi połaciami przeszkleń pomiędzy nimi (il. 20). Symetryczna fasada ujęta parą bezokiennych, wysuniętych przed lico, masywnych dzwonnic, z trzema wejściami w pierwszej kondygnacji, ma ponad nimi trzy wielkie pionowe okna rozcinające ją niemal po dach. Oceniano, że „kościół zaprojektowany został w stylu wybitnie nowoczesnym” ${ }^{\prime 39} \mathrm{i}$ zbudowany „,W charakterze bardziej powściągliwego i nie tak skrajnego modernizmu"40.

Zwieńczeniem założenia Dowództwa Floty na Oksywiu był wystawiony na placu przed budynkiem bramnym, a więc w punkcie zbiegu głównych osi założenia koszarowego, pomnik Bitwy pod Oliwą ${ }^{41}$. Inicjatywa budowy pomnika powstała w 1929 r. i zapewne już wtedy Lelewicz przygotował projekt. Przewidywał on umieszczenie dwóch tablic upamiętniających bitwę oliwską i marynarzy,

38 Ibidem, s. 327, il. 21-23; Sołtysik, Gdynia, miasto dwudziestolecia..., s. 365-367.

39 Budowa kościoła garnizonowego Marynarki Wojennej, „Przegląd Budowlany” 1934, nr 8-9, s. 1901. Por też Hanna Faryna-Paszkiewicz, Geometria wyobraźni. Szkice o architekturze dwudziestolecia międzywojennego, Gdańsk 2003, s. 76-83.

40 Budownictwo wojskowe..., t. 1, s. 440.

${ }^{41}$ Święto Morza w Gdyni, „Polska Zbrojna” 1934, nr 41, s. 3. 


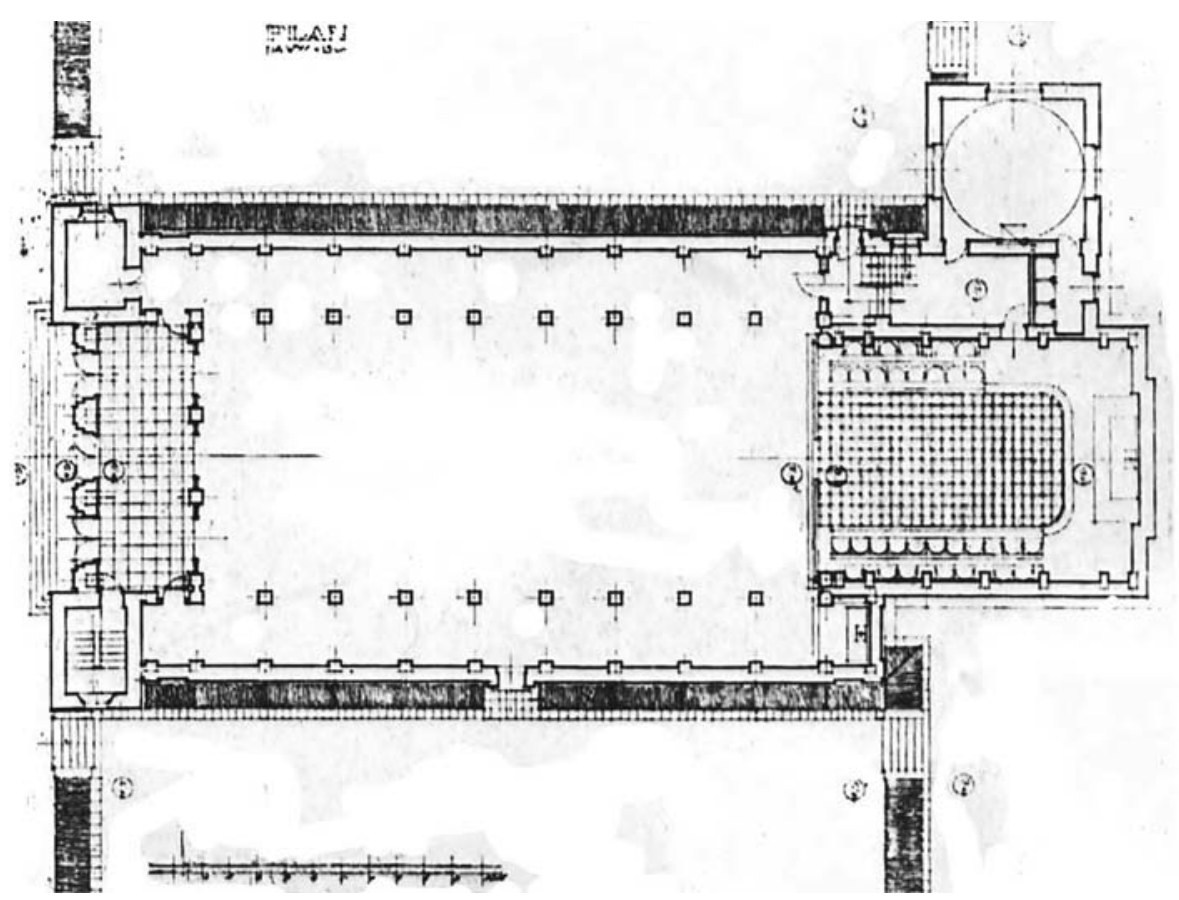

Gdyńska

architectura

militaris..

Il. 19. Projekt kościoła garnizonowego na Oksywiu, rzut, proj. Marian Lalewicz, „Architektura i Budownictwo" 1933, nr 10-12, s. 327, il. 23

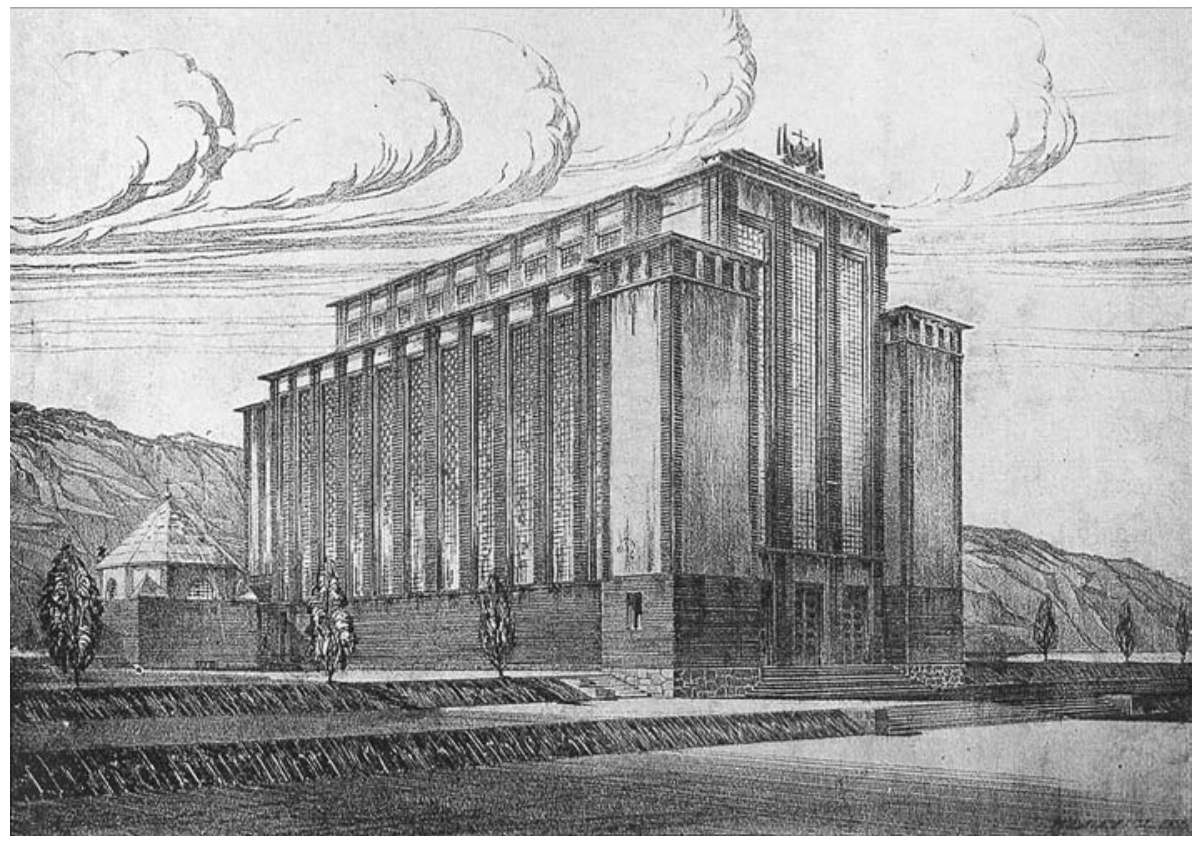

Il. 20. Projekt kościoła garnizonowego na Oksywiu, widok, proj. Marian Lalewicz, "Architektura i Budownictwo" 1933, nr 10-12, s. 327, il. 21 
Małgorzata którzy oddali życie w wojnie polsko-bolszewickiej, a jego ozdobą miały być działa, Omilanowska kule i kotwice z czasów bitwy oliwskiej, wydobyte w 1928 r. podczas budowy portu gdyńskiego ${ }^{42}$. W końcu pomnik odsłonięto dopiero 10 lutego 1934 r., w dzień święta Marynarki Wojennej. Lalewicz w ostatecznej wersji zaprojektował pomnik w formie kamiennego prostopadłościanu ozdobionego dziobami okrętów, nawiązujący kształtem i dekoracją do kolumn rostralnych (il. 21). Siedemnastowieczne działa umieszczono zaś w niszach bramy wiodącej do zespołu. Oczywistą inspiracją wyboru upamiętnienia wykorzystującego motyw kolumny rostralnej była dla Lalewicza para kolumn rostralnych zdobiących tzw. Striełkę, cypel Wyspy Wasiliewskiej, oblany wodami Newy i Małej Newy.

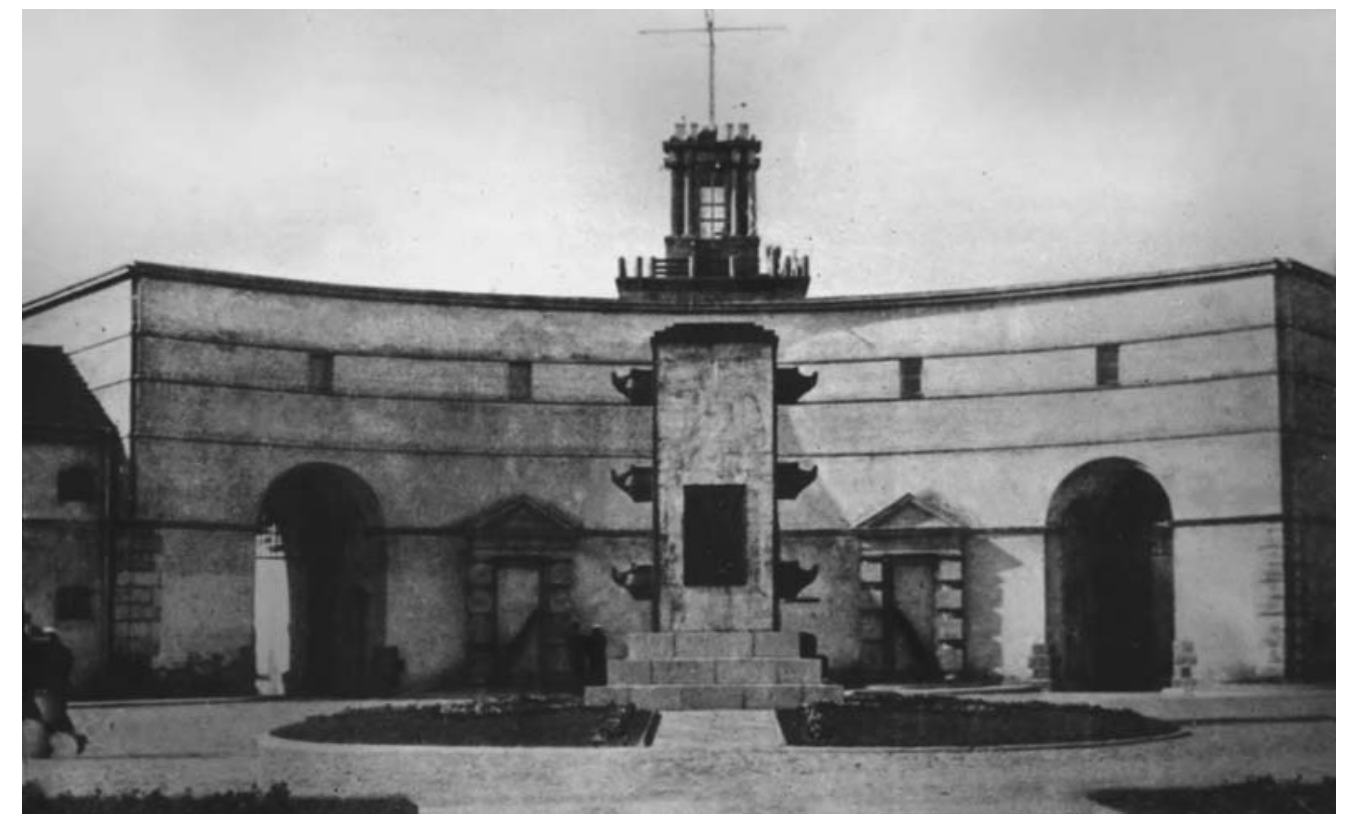

Il. 21. Gdynia, pomnik Bitwy pod Oliwą przed bramą Dowództwa Floty i koszar Marynarki Wojennej na Oksywiu, zbiory Muzeum Miasta Gdyni

Zaprojektowany przez Lalewicza oksywski zespół Dowództwa Floty i koszar Marynarki Wojennej był ówcześnie wysoko oceniany. Oczywiście, krytyka architektoniczna w odniesieniu do inwestycji publicznych, zwłaszcza w sferze wojskowej, miała raczej charakter panegiryczny, ale niemal we wszystkich opracowaniach zajmujących się budowlanymi inwestycjami dla wojska dziełu Lalewicza poświęcano specjalną uwagę.

Piszący o ówczesnej architekturze wojskowej byli świadomi jej znaczenia dla budowania wizerunku państwa. Stanisław Woźnicki podkreślał, że „udziałem architektury budowli wojskowych wszech czasów było uzmysłowienie potęgi,

42 Jacek Dworakowski, Pomnik oliwski, „Rocznik Gdyński” 1989-1990, nr 9, s. 159-161. 


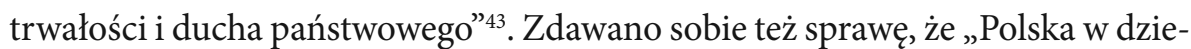
dzinie budownictwa wojskowego odziedziczyła po zaborcach spadek żałosny. [...] Gmachy nowe, wznoszone przez zaborcze władze wojskowe, przenosiły na nasz teren jak najgorsze obce szablony: albo koszarowe gmachy budowlane bez wszelkich ambicyj architektonicznych, albo, co bynajmniej nie było lepsze, pretensjonalne budowle, reprezentujące u nas najgorsze prądy architektoniczne, noszące wrogie, a co najmniej obce nam piętno pseudostylu, niezwiązanego niczym ani z tradycjami naszej rodzimej architektury, ani z charakterem kraju" ${ }^{4}$. Dlatego jedynym okresem w dziejach polskiej architektury, do której ówcześni architekci mogli nawiązać w swych projektach, był klasycyzm. Jak pisano na łamach monumentalnego opracowania Budownictwo wojskowe 1918-1935: „Pierwszy okres polskiej architektury wojskowej [...] był okresem poszukiwania nawiązań do własnej tradycji, w praktyce - nawrót do klasycyzmu. [...] działało tu silnie i to, że właściwie z okresem klasycyzmu łączą się tradycje nowoczesnej polskiej wojskowości. Klasycyzm stanisławowski, styl cesarstwa czy też klasycyzm Królestwa Kongresowego budził wspomnienia wielkich bohaterskich kart z dziejów wojska polskiego. Zwrócenie się więc przede wszystkim do budowli z tego okresu jest aż nadto zrozumiałe" 45 .

Czytelne nawiązanie do klasycyzmu w projektach Lalewicza szybko wpisało jego dzieło w ciąg najważniejszych realizacji wojskowych lat dwudziestych ${ }^{46}$. Woźnicki we wstępie do omówienia "Wystawy Budownictwa Wojskowego", która odbyła się jesienią 1933 r., podsumowując dorobek w tym zakresie, uznał zespół na Oksywiu za jedno z trzech największych osiągnięć - obok gmachu Ministerstwa Spraw Wojskowych Czesława Przybylskiego i zespołu koszarowego w Kielcach Edgara Norwertha - „podjętych z wyraźnym nastawieniem na odnalezienie właściwego charakteru militarnego architektury wojskowej” ${ }^{47}$. Stwierdził, co ciekawe, że oksywskie założenie to kompleks budynków „owianych duchem wysokiego renesansu (mur wejścia głównego!) i będących również poważną próbą określenia charakteru militarnego w architekturze"48.

Reporter czasopisma „Morze” z entuzjazmem donosił, że „wszystkie budynki są w ścisłym związku z naszymi o najlepszych tradycjach europejskich monumentalnymi budynkami historycznymi. [...] Całość [...] jest nowoczesna, piękno połączone jest $\mathrm{z}$ celowością i ekonomią i stanowić będzie pomnik budownictwa polskiego nad morzem" ${ }^{49}$.

43 Stanisław Woźnicki, Architektura Wojskowa. Z powodu wystawy piętnastolecia budownictwa wojskowego, „Architektura i Budownictwo” 1933, nr 10-12, s. 293-294, tu s. 293.

${ }^{44}$ Budownictwo wojskowe..., t. 1, s. 539.

45 Ibidem, s. 543

Ibidem, s. 549

47 Stanisław Woźnicki, Architektura Wojskowa...., s. 293-294, tu s. 294.

$48 \quad$ Ibidem..., s. 294.

49 Marynarka Wojenna..., s. 11. 
Małgorzata Omilanowska
Analizując architekturę zespołu Dowództwa Floty i koszar Marynarki Wojennej, trzeba wziąć pod uwagę niezwykle szeroki wachlarz potencjalnych związków i źródeł inspiracji. Przy tak wysokich kompetencjach architektonicznych i doświadczeniu zawodowym, jakie miał Lalewicz, należy założyć, że architekt dobrze znał dorobek architektury polskiej i europejskiej. Władał znakomicie kilkoma językami i sporo podróżował. A zatem każde skojarzenie jego projektu z wcześniejszą realizacją europejską może być uprawnione. Jednocześnie jednak trzeba zdawać sobie sprawę z faktu, że wysokie kwalifikacje i talent twórcy stanowiły podstawę do wykreowania dzieła indywidualnego, czerpiącego swobodnie z dorobku przeszłości, ale w sposób kreatywny i samodzielny, trudno więc w takim przypadku o wskazanie konkretnych wzorców.

Analiza gmachu Dowództwa Floty wiedzie do rozlicznych wzorów reprezentacyjnych budowli nowożytnych, bo i idealnie symetryczna kompozycja dynamicznego układu brył podporządkowanych osi wyniosłej wieży, i ograniczony, ale wyrazisty detal kojarzący się z surowym, rewolucyjnym klasycyzmem, mający też wcześniejsze wzorce we włoskim renesansie i baroku, otwierają tu szerokie pole do interpretacji.

Pozostałe budynki - koszarowe, gospodarcze i mieszkalne - zostały zaprojektowane zgodnie $\mathrm{z}$ normami obowiązującymi w połowie lat dwudziestych w budownictwie wojskowym, a ich formy architektoniczne wpisują się w zachowawczy nurt architektury tego czasu - co przejawia się głównie w symetrii kompozycji i wysokich dachach - nie rezygnując z oszczędnej gry detalem architektonicznym. W przypadku budynków zaprojektowanych w pierwszej fazie, w 1924 r., czytelne są jeszcze elementy jednoznacznie nawiązujące do przeszłości - portale, portyki - ale w późniejszych projektach widać, że Lalewicz ograniczył się praktycznie do operowania pionami boniowanych lizen.

Klasyczne formy, do których architekt się odwołał, projektując kompleks na Oksywiu, przywołują na myśl przede wszystkim sposób operowania spuścizną antyku w kształtowaniu architektury, jaki charakteryzował Ledoux. Nieodparte skojarzenia budzi przede wszystkim z królewskimi salinami w Arc-et-Senans, choć oczywiście o żadnych bezpośrednich zapożyczeniach ani też o naśladownictwie nie ma mowy. Niemniej w obu tych zespołach wychwycić można takie cechy, jak operowanie triadą identycznej wysokości arkad - np. na Oksywiu w budynku bramnym, a w salinach w portykach bocznych budynków frontowych, czy predylekcja do wydatnych boniowań w narożach i tzw. kolumn w okowach.

Już Andrzej K. Olszewski - określając twórczość Lalewicza ukutym przez siebie terminem klasycyzm akademicki - zauważył, że zabudowania na Oksywiu, w przeciwieństwie do projektów banków tego architekta, są „nieco modernizujące w sensie ograniczenia detalu”, choć „utrzymane... w duchu spuścizny antycznej" ${ }^{\prime 5}$. Pomimo utrwalonej w literaturze tradycji nazywania tego zespołu

50 Andrzej K. Olszewski, Nowa forma w architekturze polskiej 1900-1925. Teoria i praktyka, Wrocław-Warszawa-Kraków 1967, s. 135. 
terminem klasycyzm akademicki ${ }^{51}$ rezygnuję ze stosowania tego określenia w tym przypadku ${ }^{52}$. Niewątpliwie budynki oksywskie wyrastają z ducha umiłowania do tradycji antycznej w różnych redakcjach, bo i włoskiego renesansu, zwłaszcza Sebastiana Serlia, i francuskiego klasycyzmu, szczególnie Ledoux, i petersburskiego neoklasycyzmu po 1910 r., nie bez wpływu twórczości Andrieja Biełogruda, Władimira Szczuki czy Mariana Peretiatkowicza, a zwłaszcza takich jego projektów, jak Rosyjski Bank Handlowy. Petersburskich odniesień w projektach dla Oksywia - jak starałam się to wykazać - jest wiele, ale świadczą o doskonałej znajomości pejzażu urbanistyczno-architektonicznego tego miasta, niekoniecznie w kontekście wykształcenia akademickiego. Lalewicz był zafascynowany antykiem, pisał przez lata rozprawę Hellada, której rękopis przepadł w czasie wojny, i niewątpliwie spuścizna klasyczna jest jednym z kluczy do zrozumienia jego twórczości i architektury zespołu oksywskiego. Poszukiwania formy odpowiedniej dla architektury władzy, a raczej zbrojnego ramienia tej władzy, kazały Lalewiczowi umieścić swe dzieło w sieci odniesień zarówno uniwersalnych - królewskie saliny w Arc-et-Senans, urbanistyczny układ cesarskiej stolicy - jak i narodowych, doskonale kojarzonych przez mu współczesnych z polskim dorobkiem architektury obronnej czasów stanisławowskich i wojen napoleońskich. Jednocześnie jednak architekt potrafił wykreować dzieło o wielkich walorach syntetycznych i monumentalnych, bez zbędnej archeologiczności detalu, operujące daleko idącymi uproszczeniami.

Warto zauważyć, że na tle architektury koszar oksywskich wyraźnie odróżniają się stylistycznie dwie realizacje z lat trzydziestych - kościół i szpital - których formy nie mają już wiele wspólnego ze zmodernizowanym klasycyzmem projektów z pierwszej dekady niepodległości. Ten dość zasadniczy zwrot stylistyczny w twórczości Lalewicza, czytelny od początku lat trzydziestych, mógł oczywiście wynikać z elastyczności twórczej i otwartości na nowinki. Ale wydaje się, że tej zmianie - jak najbardziej przez architekta zaakceptowanej - pomógł impuls zewnętrzny, jakim było pojawienie się u jego boku, najpierw nieformalnie, a po 1933 r. już oficjalnie, nowego partnera zawodowego - syna Witold Lalewicza, absolwenta Wydziału Architektury Politechniki Warszawskiej z 1933 r.

Kryzys ekonomiczny zmusił Mariana Lalewicza do zamknięcia dobrze prosperującej pracowni i zwolnienia zatrudnianych tam architektów i pomocników $^{53}$, a zaangażowanie w pracę dydaktyczną i organizacyjną na Politechnice Warszawskiej znacznie ograniczyło działalność projektową architekta. Syn pracował razem $\mathrm{z}$ ojcem, ale niewiele stworzył pod własnym nazwiskiem; $\mathrm{z}$ reguły projekty sygnowane były tylko przez Mariana, choć bez wątpienia jego syn

51 Sołtysik, Gdynia, miasto dwudziestolecia..., s. 68; Pakizer, Architektura budynków koszarowych..., s. 26-27; Chłopecki, Piaseczny, Gmachy Akademii Marynarki Wojennej..., s. 55.

52 Pomijam tu w ogóle kwestię zasadności stosowania tego terminu, niemającego odpowiednika w literaturze obcej.

53 Edward Usakiewicz, Wspomnienia o profesorze Marianie Lalewiczu, „Kwartalnik Architektury i Urbanistyki” 2005, t. 50, z. 3-4, s. 201-205. 
Małgorzata Omilanowska je współtworzył i był poniekąd współodpowiedzialny za ów stylistyczny zwrot, tak wyraźnie widoczny w twórczości ojca. Znikają naczółki i wysokie dachy, klasyczne porządki i podziały, a - przy zachowaniu symetrii w komponowaniu bryły - pojawiają się podziały żebrowaniami z klinkieru i operowanie dużymi płaszczyznami przeszkleń. Marian Lalewicz w latach trzydziestych stał się przedstawicielem nurtu - jak nazywał to zjawisko Olszewski - „półmodernizmu”, czyli nieawangardowej architektury nowoczesnej.

Zespół Dowództwa Floty i koszar Marynarki Wojennej na Oksywiu w Gdyni stanowi do dziś jedną z najlepszych i największych realizacji architektonicznych, nie tylko czasów II Rzeczypospolitej, ale i całej architektury nowoczesnej, o przemyślanym układzie urbanistycznym, spójnej stylistyce i czytelnej wymowie ideowej. Dziś zubożony jest jedynie o zniszczony w czasie wojny pomnik bitwy pod Oliwą, który niewątpliwie warto by zrekonstruować.

\section{Bibliografia}

Boreyko Józef, Marynarka wojenna [w:] Dziesięciolecie odrodzenia Polskiej Siły Zbrojnej 1918-1928, red. Henryk Mościcki, Włodzimierz Dzwonkowski, Tadeusz Bałaban, Warszawa 1928, s. 456-472.

Budownictwo wojskowe 1918-1935. Historia, przepisy, zasady, normy, red. Aleksander Król, t. 1-2, Warszawa 1935.

Chłopecki Jerzy, Piaseczny Bogdan, Gmachy Akademii Marynarki Wojennej [w:] Ochronazabytków architektury obronnej. Materiały Ogólnopolskiego Zjazdu Społecznych Opiekunów Zabytków i Wojewódzkich Konserwatorów Zabytków, Gdynia - Hel, 2-4 października 1998 r. W 80. rocznicę powstania Marynarki Wojennej RP, red. Bronisław Grzegorczyk, Gdynia-Hel 1998, s. 54-62.

Ciesielski Czesław, Powstanie Marynarki Wojennej i jej udział w rozwoju Gdyni [w:] Dzieje Gdyni, red. Roman Wapiński, Wrocław-Warszawa-Kraków-Gdańsk 1980, s. 62-74.

Dankiewicz Katarzyna, Marian Lalewicz [w:] 100 lat Wydziału Architektury Politechniki Warszawskiej 1915-2015. Nauczyciele, red. Jadwiga Roguska, Stefan Wrona i in., Warszawa 2018, s. 341-343.

Domy mieszkalne Funduszu Kwaterunku Wojskowego. Sprawozdanie 1927-1930, Warszawa 1930.

Dworakowski Jacek, Pomnik oliwski, „Rocznik Gdyński” 1989-1990, nr 9, s. 159-161.

Faryna-Paszkiewicz Hanna, Geometria wyobraźni. Szkice o architekturze dwudziestolecia międzywojennego, Gdańsk 2003.

Kibort Piotr, Marian Lalewicz, Culture-pl, https://culture.pl/pl/tworca/marian-lalewicz [dostęp: 10.09.2019].

Kirikow Boris, Architektura pietiersburgskogo moderna. Obszczestwiennyje zdanija. Kniga Wtaraja, Sankt Petersburg 2019.

[Lewoszko Swietłana] Левошко Светлана, С., Лялевич Марианн Станиславович, http://www.artrz.ru/search/Лялевич [dostęp: 20.08.2019]. 
Łobecki Jan Moderst, Architectura militaris Polona 1918-1978 [w:] Architektura i urbanistyka w Polsce w latach 1918-1978, Warszawa 1989 (Studia i Materiały do Teorii i Historii Architektury i Urbanistyki, t. 18), s. 93-120.

Niemojewski Lech, Wspomnienie pośmiertne: Marian Lalewicz (1876-1944), „Rocznik Towarzystwa Naukowego Warszawskiego" 1938-1945, nr 31-38, s. 212-214.

Olszewski Andrzej K., Nowa forma w architekturze polskiej 1900-1925. Teoria i praktyka, Wrocław-Warszawa-Kraków 1967.

Omilanowska Małgorzata, Działalność Mariana Lalewicza w Petersburgu, „Przegląd Wschodni” 1991, nr 1, s. 113-132.

Pakizer Angelika, Architektura budynków koszarowych Marynarki Wojennej projektu Mariana Lalewicza na Oksywiu, Gdańsk 2004, praca mgr napisana na Wydziale Historycznym Uniwersytetu Gdańskiego, mpis.

Pasieczny Robert, Gusta kupca Mertensa [w:] De Gustibus: studia ofiarowane przez przyjaciół Tadeuszowi Stefanowi Jaroszewskiemu z okazji 65 rocznicy urodzin, red. Robert Pasieczny, Antoni Ziemba, Warszawa 1996, s. 202-211.

Pasieczny Robert, Klasycyzm akademicki w twórczości Mariana Lalewicza [w:] Klasycyzm i klasycyzmy, Warszawa 1994, s. 205-209.

Pruszyński Jan, Profesor Marian Lalewicz (1876-1944), „Kwartalnik Architektury i Urbanistyki” 1993, z. 1, s. 57-70.

Roguska Jadwiga, Petersburskie wątki w warszawskiej twórczości architektonicznej Mariana Lalewicza, t. 6, Polscy i rosyjscy architekci XIX $i$ XX wieku, red. Jerzy Malinowski, Irina Gavrash, Warszawa-Toruń 2018, s. 133-154.

Skalimowski Andrzej, Marian Lalewicz, http://www.polskipetersburg.pl/hasla/lalewicz-marian [dostęp: 10.08.2019].

Sołtysik Maria J., Gdynia miasto dwudziestolecia międzywojennego. Urbanistyka i architektura, Warszawa 1993.

Sprawozdanie Funduszu Kwaterunku Wojskowego 1927-1937, Warszawa 1938.

Usakiewicz Edward, Wspomnienia o profesorze Marianie Lalewiczu, „Kwartalnik Architektury i Urbanistyki” 2005, z. 3-4, s. 201-205.

Wagner Agata, Gmach Państwowego Instytutu Geologicznego w Warszawie - przestrzenno-architektoniczne odniesienia Mariana Lalewicza do klasycyzmów w architekturze polskiej, „Kwartalnik Architektury i Urbanistyki” 2010, z. 4, s. 88-102.

Wagner Agata, Niezrealizowane plany Mariana Lalewicza rozbudowy Politechniki Warszawskiej na Polu Mokotowskim, „Kwartalnik Architektury i Urbanistyki” 1998, z. 4, s. 343-352.

Woźnicki Stanisław, Architektura Wojskowa. Z powodu wystawy piętnastolecia budownictwa wojskowego, „Architektura i Budownictwo” 1933, nr 10-12, s. 293-294.

Zachwatowicz Jan, Lalewicz Marian [w:] Polski słownik biograficzny, t. 16, WrocławWarszawa-Kraków 1971, s. 413-414.

\section{Gdynia's Architectura Militaris Authored by Marian Lalewicz}

The complex of the Fleet Command and Navy barracks at Gdynia's Oksywie is one of the most interesting examples of military architecture of the Second Polish Republic. The extensive urban and architectural complex was the work of one architect Marian 
Małgorzata Lalewicz; raised over a brief period of time, in its core it represented architectural homoOmilanowska geneity. It was one of the first projects on such a scale of the Polish army after Poland had regained independence. The whole was to be composed of the Fleet Command premises as well as the buildings of the Navy barracks, together with the organizational and technical infrastructure, and dwelling houses for non-commissioned officers and officers together with their families. Lalewicz laid out the whole complex using the radial scheme. The axis of the scheme was to be found in a roundabout closed from the north with a gatehouse on the layout of a quarter circle whose three gateways marked out three axes of the complex. The middle one led to the building of the Fleet Command, the right (eastern) was the backbone for the dwelling complex for the non-commissioned officers and officers, while the left one (western) led along auxiliary buildings to the non-commissioned officers' house, and its eastward bifurcation continued to the barrack complex in a form of a square of buildings placed around the trapezium drill ground. The design having been created in 1924, its implementation conducted in stages was completed in 1931. The complex was subsequently added a hospital building, a garrison church, and, in 1934, the monument commemorating the Battle of Oliwa.

The classical forms Lalewicz echoed in his design for the Oksywie complex make one first of all recall the application of the legacy of the antiquity in shaping architecture characteristic of Jean Nicolasa Louisa Ledoux, though also the Italian Renaissance is referred to, particularly Sebastiano Serlio, and St Petersburg's Neo-Classicism after 1910, with some impact of the oeuvre of such architects as Andriey Bielogrud, Vladimir Shchuko, or Marian Peretyatkovich, particularly such of his designs as Russia Trade Bank. Search for the form adequate to the architecture of power, or more strictly speaking its armed forces, made Lalewicz place his work within the network of both universal references: Royal Saltworks at Arc-et-Senans, urban layout of the imperial capital, and the national ones: perfectly associated by the contemporary with the Polish accomplishments of military architecture from King Stanislaus Augustus' times and Napoleonic wars. The Oksywie Fleet Command and Navy barracks complex has remained one of the best and grandest architectural implementations not only from the period of the Second Polish Republic, but also of all modern architecture, of thoroughly thought-out urban layout, coherent stylistics, and transparent ideological message. 